\title{
Trade Flows and Trade Disputes
}

\author{
Chad P. Bown ${ }^{\dagger}$ \\ The World Bank and CEPR
}

\author{
Kara M. Reynolds \\ American University
}

This version: July 2014

\begin{abstract}
This paper introduces a new data set and establishes a set of basic facts and patterns regarding the 'trade' that countries fight about under WTO dispute settlement. It characterizes the scope of products, as well as the levels of and changes to the trade values, market shares, volumes, and prices for those goods that eventually become subject to WTO litigation. The first result is striking heterogeneity in the level of market access at stake across disputes: e.g., 14 percent of cases over disputed import products feature bilateral trade that is less than $\$ 1$ million per year, and another 15 percent feature bilateral trade that is more than $\$ 1$ billion per year. Nevertheless, some strong patterns emerge from a more detailed examination of the data. Both high- and low-income complainants tend to suffer important losses in foreign market access in the products that ultimately become subject to dispute. Furthermore, while the respondent's imposition of an allegedly WTO-inconsistent policy is associated with reductions, on average, to trade values, volumes and exporter-received prices, there is some evidence of differences in the size of these changes across both the different types of policies under dispute and the potential exporter country litigants. Finally, these different types of policies under dispute can have dissimilar trade effects for the complainant relative to other (non-complainant) exporters of the disputed product, and this is likely to affect the litigation allegiance of third countries.
\end{abstract}

Keywords: dispute settlement, WTO, trade agreements

\footnotetext{
${ }^{\dagger}$ Bown: Development Research Group, Trade and International Integration (DECTI); The World Bank, $1818 \mathrm{H}$ Street NW, MSN MC3-303, Washington, DC 20433 USA; Tel: +1.202.473.9588, fax: +1.202.522.1159, email: cbown@worldbank.org, web: https://sites.google.com/site/chadpbown/

"Reynolds: Department of Economics, American University; 4400 Massachusetts Avenue, NW, Washington, DC 20016 USA; Tel: +1.202.885.3768, fax:+1.202.885.3790, email: reynolds@american.edu, web: http://nw08.american.edu/ reynolds

Thanks to comments from Todd Allee, Lawrence Broz, Marc Busch, Stephen Chaudoin, Paola Conconi, Christina Davis, Axel Dreher, Manfred Elsig, Robert Feinberg, Andreas Fuchs, Judith Goldstein, Henrik Horn, Doug Irwin, Leslie Johns, Andrew Kerner, Soo Yeon Kim, Petros Mavroidis, Niall Meagher, Helen Milner, Krzysztof Pelc, Tom Prusa, Frieder Roessler, Robert Staiger, Alan Sykes, Michael Trebilcock, participants at the PEIO Conference at Princeton, at the Challenges to World Trade System Conference at Stanford, at seminars at the ACWL and EUI, and three anonymous referees. We acknowledge the generous financial support from the World Bank's KCP Trust Fund. Thanks to Aksel Erbahar and Carys Golesworthy for excellent research assistance. Any opinions expressed in this paper are the authors' and should not be attributed to the World Bank. All errors and omissions are our own.
} 


\section{Introduction}

WTO dispute settlement inherently concerns a complainant country's protection of its foreign market access interests. Nevertheless, what 'trade' are countries fighting over when they utilize this extremely high profile system? To begin, are disputes mainly about the restoration of lost market access after a country has implemented a new WTO-inconsistent policy? Or are disputes an attempt to reach expected levels of market access that have yet to be realized because a member has so far failed to change a policy so as to bring it into compliance with new WTO commitments or obligations? Furthermore, are the trade flows under dispute large or small, and relative to what benchmarks and counterfactuals? Do disputes concern changes in trade volumes, or are they about adverse implications for prices, and thus the international terms of trade? Does this depend on the countries involved? Is it affected by the types of policies being challenged, such as whether the policy is applied to all, or only some, trading partners?

While political-economic research on the WTO's dispute settlement system has increased prolifically, surprisingly little is known about even the basic characteristics of the levels of and changes to exports and imports of the disputed products that catalyze WTO members' use of the system. The purpose of this paper is to begin to address this particular void by providing an examination of the trade involved in the first 17 years of WTO litigation. We establish a set of basic facts regarding the trade content of the observed WTO dispute settlement caseload, we use the patterns to raise questions for future research, and our approach is structured to provide two main contributions to the political-economic literature.

Our first contribution is to construct a new database that maps information on the policies that trigger WTO disputes to product-level trade data so as to potentially learn from more precise measures of market access. This mapping includes three important elements that, to our knowledge, have not yet been fully exploited by the literature: i) information on the timing of the respondent's policy change which triggered the dispute, which is frequently different from what we argue is the less informative timing of the complainant's initiation of the dispute; ii) the different types of WTO-violating policies imposed, and iii) the different trading partners directly impacted by the respondent's policy change.

The first element has implications for what can be inferred from data on the levels of and changes to bilateral trade flows. For the second and third elements, we also distinguish between respondent policies applied in a way that can negatively affect all trading partners - what we term 'global' policies versus policies applied in a way that negatively affect only selected trading partners - what we term 'partial' policies. 'Global' policies - such as WTO-inconsistent application of an internal tax, subsidy, or other regulation that is nevertheless imposed on a most-favored-nation (MFN) conforming basis - 
discriminate between import-competing domestic firms and all foreign producers of the disputed products, implying that other, non-complainant trading partners also face the same policy. On the other hand, 'partial' policies - such as application of a WTO-inconsistent antidumping or countervailing duty or preference scheme - also discriminate between different foreign producers. In these disputes, some trading partners do not face the policy and may benefit from it being imposed on foreign peers, resulting in economic interests that are more in line with the respondent than the complainant.

Our second contribution is to provide an empirical approach that is simple and transparent. It can be easily replicated, refined, extended and used in other applications. An important goal of this work is to provide a characterization of observed trade patterns that might motivate its inclusion in future theoretically-motivated research. However, so as to make the source of our results clear, we generally refrain from imposing onto the analysis any particular modeling structure or additional set of assumptions. We establish facts based on both summary statistics and information from the full distribution of the disputed product trade data arising under the useable WTO caseload. And while we provide potential explanations for observed patterns in order to motivate avenues for additional research, for the most part we use only basic economic theory to interpret our results. ${ }^{1}$

Our formal analysis allows us to report market access characteristics of nearly three quarters of all WTO disputes initiated between 1995 and 2011. We focus on disputes that allege WTO-inconsistent market access policies that affect product-level imports and find that WTO dispute settlement proceedings scrutinized nearly $\$ 1$ trillion in imports over this period. This works out to an average of $\$ 55$ billion per year, or roughly 0.5 percent of the level of world imports in 2011. Furthermore, of the subsample of WTO member challenges to import-restricting policies, we find that more the three quarters of the disputes can be linked to observed policy changes. This suggests that complainants are typically concerned with the restoration of lost market access. In the aggregate for these disputes, and without controlling for other factors that are also likely to impact trade flows, imports in the disputed products turn out to be $\$ 60$ billion less in the year after the disputed policy change relative to their levels in the year prior to the change. Combined, these two sets of aggregated statistics suggest there are economically meaningful trade and market access interests directly at stake in WTO disputes. And these measures do not even attempt to consider the many undoubtedly important indirect market access implications of WTO jurisprudence and the resulting 'shadow of the law.'

\footnotetext{
${ }^{1}$ We do not examine any data on outcomes of WTO dispute settlement, and our comparisons are drawn only from the product markets that are subject to actual WTO disputes. Therefore, we limit our discussion to what can be learned from such an exercise, and we deliberately attempt not to extrapolate from our results to inform understanding of policies imposed by WTO members that have gone unchallenged by formal dispute settlement.
} 
Next, in terms of our detailed analysis across disputes, our most remarkable result is that the levels of bilateral trade in disputed products subject to the underlying formal WTO litigation are extremely heterogeneous in size and scope. First, roughly 14 percent of these disputes involve bilateral (complainant-respondent) trade in disputed products of less than $\$ 1$ million per year, while another 15 percent of disputes involve bilateral trade in disputed products of more than $\$ 1$ billion per year. To put the scale into some perspective, the frequency of small stakes disputes is somewhat striking given that private sector costs associated with litigating even the most straightforward dispute to a basic Panel Report start at roughly $\$ 250,000$. Second, nearly 20 percent of the disputes have a complainant focused on the market access of one product at a time, whereas another 20 percent of the disputes feature a complainant challenging a policy that is so broad that it affects over 50 different products at once. Combined, these facts seem to imply that WTO disputes can arise anywhere and may be difficult for political-economic research to ultimately explain.

Yet even with this apparently overwhelming evidence of heterogeneity in the distributions of the scope of products and levels of market access under dispute, sensible patterns emerge from a more detailed examination of the data. For example, once we condition on disputes that involve allegations of policy changes - as opposed to allegations of the failure to change policies to bring them into compliance with the terms of the WTO Agreements - there are economically meaningful inter-temporal changes to the trade variables associated with the timing of the imposition of the (allegedly WTO-inconsistent) policy for both high- and low-income complainant countries. And while it is not surprising that disputes with high income complainants involve levels of disputed product trade and market access that are larger in value terms, low-income complainants also suffer significant foreign market access losses in the products under dispute when measured as shares or as growth rates.

In addition to a standard examination of the value of trade under dispute, we exploit the productlevel nature of our data to decompose the changes in the value of trade associated with the imposition of disputed policies to the relative changes occurring in trade volumes and prices. How prices change in response to policy changes may be particularly important given the terms-of-trade theory of trade agreements (Bagwell and Staiger, 2002), which suggests that trade agreements - and by extension, litigation that challenges policy changes occurring under such agreements - may help governments refrain from implementing levels of import protection that are 'excessive' in that they impose externality costs on trading partners. Externalities can arise through the exertion of market power, and there is increasing empirical evidence that the terms-of-trade theory has critical implications for how countries 
conduct their import policy, both outside and inside the WTO system. ${ }^{2}$ And while our evidence of patterns in the exporter-received price data is admittedly weaker than our other results, partially due to the standard problems associated with reliance on price data constructed from unit values, we argue that the evidence is sufficiently suggestive to warrant treating WTO dispute settlement as a useful environment in which to further examine implications of this theory for government policy choices.

In particular, our results suggest differences across disputes depending on whether the alleged policy being challenged was a 'global' versus a 'partial' policy, in terms of how the respondent applied the policy to non-complainant trading partners. While we find little statistical difference in the levels of respondent imports from complainants in disputes between the two different sets of policies, there is some evidence of differences to changes in exports to the respondent depending on the type of policy under dispute. In particular, we find that global policies under dispute are associated with smaller reductions in import values and volumes and potentially larger reductions in the complainant's export-received prices when compared to disputes associated with partial policies.

As a final step we use our approach to make comparisons between complainant and noncomplainant exporters of the disputed product to the respondent country for the 'global' types of disputes in which the respondent's policy was applied to all trading partners. We find that relative to noncomplainants, complainants have larger exports and market share. Likewise, among all exporters of the disputed product to the respondent, many of which could have alternatively initiated the dispute, complainants experience the strongest impact of the policy imposition to changes in their export values, volumes, market shares, and prices. This raises the question of whether their substantial market access at stake helps them overcome the collective active problem and free-riding (Olson, 1965) that might otherwise inhibit dispute initiation. Finally, we also find that complainants in these disputes are typically the low-priced exporter of the disputed products in the respondent's market.

Why is it important to characterize the levels of and changes to the market access that trigger WTO disputes? One motivation is that, to our knowledge, even this relatively straightforward construction of basic facts has not yet been undertaken. And while research examining WTO dispute settlement is increasing, attempts to synthesize key insights from the prior empirical literature, especially with regard to questions related to the market access under dispute, prove elusive.

\footnotetext{
${ }^{2}$ See, for example, Broda, Limão and Weinstein (2008), Bagwell and Staiger (2011), Ludema and Mayda (2013), and Bown and Crowley (2013). Bagwell and Staiger (2002) provide a book-length treatment of the terms-of-trade theory and its implication for trade agreements.
} 
A second motivation is that our results add to a growing body of research examining various aspects of the WTO's dispute settlement process. First, our results have the potential to inform the rapidly expanding theoretical literature that examines the role of dispute settlement provisions in models that treat the WTO as an incomplete contract, recent examples of which include Maggi and Staiger (2011, 2013, forthcoming) and Staiger and Sykes (2013). ${ }^{3}$ Second, most of the early research on dispute settlement was empirical and only loosely guided by theory. It typically sought evidence of correlations between some potential determinant of interest - such as a country or industry-level characteristic - and measures of activity related to WTO (and GATT-era) disputes. Measures of this activity have included examination of determinants of the decision to initiate or engage in disputes (e.g., Horn, Mavroidis, and Nordstrom, 2005; Bown, 2004a, 2005a,b; Guzman and Simmons, 2005; Davis and Bermeo, 2009; Johns and Pelc, 2013) as well as the determinants of dispute settlement outcomes. With respect to the question of outcomes, our product-level data may help inform further research into both the determinants of the legal outcomes - such as settlement versus continued litigation and rulings (e.g., Busch and Reinhardt, 2001, 2003; Reynolds, 2009) - as well as the economic outcomes - such as potential changes in trade flows resulting from the dispute (e.g., Bown 2004b,c). ${ }^{4}$

The rest of this paper proceeds as follows. Section 2 provides a brief overview of the general trends in usage of the WTO dispute settlement system over time, and it details the characteristics of the policies under WTO dispute that help narrow the focus of the rest of the paper. Section 3 introduces our variable construction and data mapping exercise and presents our baseline set of results on the characteristics of bilateral (complainant-respondent) trade values, volumes, prices, and market shares of the products under dispute, as well as potential differences for high-income versus low-income users of the system. Section 4 further refines the analysis to examine potential differences in the bilateral trade under dispute in 'global' versus 'partial' policy cases, as well as differences between complainant and non-complainant exporters of the disputed product to the respondent in these cases. Finally, Section 5 concludes.

\footnotetext{
${ }^{3}$ Other theoretical contributions to the literature on enforcement, trade agreements, and WTO dispute settlement include Beshkar (2010a,b) and Park (2011).

${ }^{4}$ Some attempts to summarize results of this empirical literature can be found in Bown (2009, chapter 4), Busch and Reinhardt (2002), and Davis (2012). Busch and Pelc (forthcoming) survey research on the cross-country concerns over limited legal capacity affecting WTO dispute settlement.
} 


\section{Macro-level Facts about WTO Disputes and Policies Being Challenged}

This section provides a brief introduction to the aggregate-level data on WTO disputes that were initiated between 1995 and 2011, before turning to a characterization and discussion of the types of policies being challenged.

\subsection{A brief introduction to WTO disputes over time and across countries}

WTO members made 427 separate requests for consultations under the dispute settlement provisions between 1995 and 2011. Figure 1 illustrates the number of disputes initiated per year according to two different case-based definitions and by two income-based categories within each definition. The first of the stacked bars refers to the standard WTO case-based definition. The second is a refined version of a case that both eliminates redundant filings - i.e., multiple disputes between the same two countries over the same issue - and takes all disputes with multiple complainants and strips them into bilateral (i.e., single complainant-respondent) pairs. This bilateral pairing definition is one that is common in the literature and which we adopt because it is particularly appropriate for our empirical analysis which seeks to characterize the bilateral trading relationships for the products under WTO dispute. ${ }^{5}$

\section{[Figure 1 here]}

Figure 1 reveals that these two definitions of dispute initiation not only result (coincidentally) in the same total number of disputes over this period, but the overall heights of the two sets of bars indicates that they also follow the same basic time trend. Our focus throughout the paper will rely exclusively on the second definition. We note from the figure that the volume of disputes has declined dramatically over time, with a sharp break around the turn of the millennium. Between 1995 and 2000, countries initiated an average of 27.8 disputes per year, whereas between 2001 and 2011 they initiated an average of nearly 10 fewer (18.2) disputes per year. Nevertheless, Figure 1 also indicates a slight increase in the relative share of cases initiated by low-income countries over time. This is partially due to a more consistent absolute number of low-income country initiated cases, and a sharp drop-off of high-income country initiated cases in the period after 2000 .

\footnotetext{
${ }^{5}$ Beginning with the 427 disputes initiated over 1995-2011 according to the standard WTO definition, an expansion that accounts for multiple complainants results in 455 bilateral pairs of countries engaged in those disputes. However, the elimination of redundant filings coincidentally reduces the total to 427 disputes under the bilateralpairs definition over this period.
} 


\subsection{Which policies do WTO disputes challenge?}

Next we describe the types of policies that WTO members typically challenge under formal dispute settlement. We provide three related characterizations of the policies under dispute which subsequently help us structure our formal empirical analysis: i) whether the policies affect particular imported products, as opposed to general import conditions, services imports, or even exports; ii) whether the policies were newly imposed or 'old' in the sense that the respondent failed to sufficiently reform them in order to bring them into compliance with new commitments in the agreement; and iii) whether the policies are applied on a 'global' or 'partial' basis - i.e., whether the respondent's alleged policy is applied to all of its trading partners or if some are excluded.

Table 1 provides a detailed summary of the breakdown of policies challenged under WTO dispute settlement cases during the 1995-2011 period that we describe in the next three subsections.

[Table 1 here]

\subsubsection{Policies that affect imported products versus general imports, services, or exports}

Begin with Table 1 and our working definition of a WTO dispute, under the bilateral (complainant respondent) pair, non-redundant characterization there were 427 initiations taking place between 1995 and 2011. Our first step is to separate the dispute settlement caseload into alleged WTO-inconsistent policies that affect exports versus those that affect imports. We find 41 disputes that affect exports, and thus we focus our analysis on the remaining 386 WTO disputes that address import policies, noting that these make up 90.4 percent of all disputes. ${ }^{6}$

\footnotetext{
${ }^{6}$ Specifically, we classify all disputes over alleged export subsidies, or violations of the Agreement on Subsidies and Countervailing Measures Article 3.1(a), as disputes over policies affecting exports, under the assumption that the complainant is concerned with the subsidy's impact on common exported products to third-country markets. We also classify as export policy disputes the much smaller number of cases over export restrictions, such as the disputes filed in 2009 against Chinese export restrictions on raw materials. The complainants in these disputes argued that Chinese export restrictions increased world prices for these commodities while at the same time subsidizing Chinese producers that use these as inputs. Although such policies are also likely to have market access implications for foreign producers (e.g., complainant exporters) in China by raising their input costs for raw materials, the resulting market access at stake would be in downstream (user) products, such as steel, and not the raw material inputs. Examination of the downstream market access implications of such policies requires inputoutput mapping and data on the specific downstream products affected by the export restrictions on the inputs. While it would be interesting to examine both these types of (excluded) disputes as well as an extended analysis of our import policy (included) disputes to assess their indirect and downstream market access implications, such an exercise is beyond the scope of the current paper.
} 
In general, we note that there are a number of research contexts in which it may be important to treat disputes over export policies differently from disputes over import policies. For example, below we use the primary litigants' (complainant-respondent) bilateral trade data in disputed products to reveal market access implications for disputes over policies that affect imports. An examination of this same bilateral (complainant-respondent) trade data is not likely to reveal comparably useful market access information for those disputes over policies that affect exports. Because the threat to a complainant's market access arises through competition in a common third country market in those disputes, data from an alternative importing country's market may be required.

Second, we identify challenges to services imports as opposed to goods imports. Once we strip out the 11 disputes that confront services policies and to which we cannot map disaggregated, productlevel trade data, we are left with 375 disputes, or 87.8 percent of the total caseload.

Our third and final step at this stage is to strip away the disputes that concern general challenges to a WTO member's legislation and that do not necessarily concern the application of a policy to any particular product(s). Examples include challenges to the United States' Antidumping Act of 1916, United States' Section 337 of its 1930 Trade Act, and United States' Sections 301-310 of the Trade Act 1974. After eliminating 67 such disputes, we are left with 308 WTO disputes, which make up 72.1 percent of the original caseload. $^{7}$

The remaining 308 bilateral disputes contain challenges to a respondent's allegedly WTOinconsistent import-restricting policy that we can subsequently map to product-level trade data as described in Section 3 below. These disputes make up the baseline sample used in the estimation.

\subsubsection{Newly imposed policies or failure to reform policies so as to bring them into WTO compliance}

Our next step is to split WTO disputes into two further categories based on whether we are able to trace them to a newly-imposed policy. Some WTO disputes cannot be linked to implementation of a new policy and instead are triggered by the failure to reform a policy so as to bring it into compliance with what the complainant alleges are that trading partner's commitments or obligations as a member of the WTO. Table 1 reveals that while most of these 308 disputes concern changes to import-restricting

\footnotetext{
${ }^{7}$ These 67 cases also include all of the violations over the WTO's intellectual property rights agreement (TRIPS); these disputes can be associated with lack of protection for a wide variety of services (i.e. movie and sound recordings) in addition to merchandise (i.e. pharmaceuticals and chemicals) products.
} 
policies, there are a significant number of disputes (68) over which the main allegation is that the respondent failed to reform a policy.

We make this characterization because it is likely important for making inferences about market access interests from directly observable trade data. For disputes challenging observable policy changes, there is arguably a period before the imposition of the policy during which the respondent was not violating its WTO commitments or obligations. For these types of disputes, examination of the trade data from prior to policy implementation may provide information on the level of a respondent country's market access commitment, and the size of the trade at stake for the complainant and other potential exporting countries. However, disputes that challenge the failure to reform 'old' policies do not have such a period in which a WTO-consistent policy was in effect. In these disputes, examination of the trade data may only provide a lower bound for the market access commitment of the respondent, as well as the potential trade interests of the complainant.

\subsubsection{Global versus partial policies and respondent's treatment of non-complainant exporters}

A final characterization of the WTO data is based on whether the policy under dispute was applied by the respondent in such a way that can negatively affect all of its trading partners - defined here as a 'global' policy - versus a policy applied in such a way that negatively affects only selected trading partners defined here as a 'partial' policy. Examples of global policies would be a WTO-inconsistent application of an internal tax, subsidy, or regulation imposed on an MFN-conforming basis. Examples of partial policies would be a WTO-inconsistent application of an antidumping or countervailing duty or trade preference scheme.

While this characterization has parallels to whether the main WTO issue is an alleged violation of national treatment (global policies) or MFN treatment (partial policies), we note that our subjective data characterization is based on only a judgment from policy information of how the respondent applied its allegedly WTO-inconsistent policy vis-à-vis non-complainant exporters. The characterization is not based, for example, on whether the complainant's formal allegation arising in the dispute refers to a claim under GATT 1947 Article I (MFN Treatment) versus Article III (National Treatment). ${ }^{8}$ Furthermore, our

\footnotetext{
${ }^{8}$ Such a reference would not be possible for all of the disputes in our sample given that not all of them move beyond the consultations stage to the formal Panel stage in which complainants must fully articulate their allegations of respondent misconduct. Furthermore, the two allegations are also not mutually exclusive. For a discussion of some of the key economic aspects of National Treatment in the GATT and WTO, see Horn (2006). For a discussion of the role of MFN Treatment, see Horn and Mavroidis (2001).
} 
characterization also does not rely on an ex post empirical assessment of observed changes to the trade flow data arising from the import policy.

Table 1 indicates that of the 240 disputes that involve the respondent making a policy change that was allegedly WTO-inconsistent, roughly 60 percent involved partial policies and 40 percent involved global policies. We ultimately utilize this characterization to empirically examine two different questions exploiting variation across the WTO dispute caseload.

The first question is whether there are differences in the changes in bilateral (complainantrespondent) trade flows associated with 'global' versus 'partial' policy disputes. Specifically, are there differences in changes to trade values, volumes, and prices, depending on whether the policy is imposed in a way that affects all versus only a selective set of other exporters of the disputed product? All else equal, theory would suggest the size of the trade effects in partial policy disputes would be larger because those policies are more targeted toward specific (complainant) exporting country trade by definition.

The second question is whether these different policies under dispute also result in additional differences between complainant and third party (non-complainant) exports of the disputed product to the respondent. In disputes over a 'global' policy, the economic interests of the third countries should be aligned with the complainant, and economic theory would predict export volumes and prices to move in the same direction as they move for the complainant's exports. In disputes over a 'partial' policy, economic theory would predict a form of trade diversion (Viner, 1950) - i.e., that the third country exporters that were excluded from a new import restriction would have export volumes and prices that move in the opposite direction than those of the complainant. These third party exporters are likely to have economic interests more aligned with import-competing producers in the respondent country (at least for that particular product under dispute) than with exporters in the complainant country.

\section{WTO Disputes: The Scope of Product Coverage, Trade Flows, and Market Shares}

This section examines the international trade associated with WTO disputes initiated between 1995 and 2011. We first describe our approach to defining variables before implementing that approach and investigating our questions of interest. 


\subsection{Variable definition, construction, and underlying data}

We begin by identifying the set of disputed products at the Harmonized System's 6-digit (HS-06) level from policies described in WTO dispute settlement documentation and other national government sources, ${ }^{9}$ which we then match against import data at the HS-06 level from UN Comtrade made available via the World Bank's World Integrated Trade Solution (WITS) database. The HS-06 level is the most disaggregated level of imports that is consistently defined across countries, and in any given year in our sample there are slightly more than 5000 such products potentially imported by any country. ${ }^{10}$ While our approach is also capable of handling the many disputes that take place at higher levels of aggregation than the HS-06 level, it is necessarily imperfect in that it will tend to overstate the dollar value of trade at stake for a few disputes in which the respondent country's alleged policy was applied at its more narrowlydefined (e.g., HS-08 or HS-10) level of aggregation.

We construct and examine a number of different measures characterizing the bilateral data for the international trade under dispute. We first define each variable of interest here; more detailed information on each variable is included in the Appendix.

Our first variables characterize the scope of products and the levels of import market access for the products subsequently under dispute. The scope of products is defined as the count of HS-06 product codes and may be used to proxy for the range of a particular policy in order to assess how difficult to overcome would be the collective action problem involved in, say, politically organizing affected firms both within and across potential complainant countries (Olson, 1965).

Next, we characterize market access levels so as to also allow for potential bilateral variation by considering the respondent country's imports from complainants, third parties, and non-participants. One measure is simply the value of bilateral imports of the disputed product in constant (2005) US dollars. An alternative measure that helps normalize issues related to importing country size is the bilateral share of the respondent's import market for the disputed product. Finally, in some applications we also examine

\footnotetext{
${ }^{9}$ For disputes involving allegations of WTO-inconsistent use of antidumping, countervailing duties, and safeguards, we also rely on information from the World Bank’s Temporary Trade Barriers Database (Bown, 2013).

${ }^{10}$ Cross-country comparisons of counts of products beyond the HS-06 level are not meaningful because countries have discretion in how to establish their HS-08, HS-10 (etc.) lines.
} 
the relative levels of exporter-received prices; i.e., prices (unit values) for the respondent's imports of the disputed products from different exporting countries. ${ }^{11,12}$

Our second set of variables characterize how these bilateral trade indicators change alongside the timing of the respondent country's imposition of an allegedly WTO-violating policy. Before describing the construction of these change variables, we define the critical year around which we choose to benchmark these changes, and we describe the logic behind this choice.

We make two arguments that the critical year of interest for our exercise is the year of the imposition of the allegedly WTO-inconsistent policy rather than the year in which the complainant initiates the WTO dispute. ${ }^{13}$ First, the imposition of a WTO-inconsistent policy may immediately begin to distort the conditions of competition and market access for the disputed product. Second, attempts to attribute changes in market access conditions - e.g., import market shares, values, volumes, or prices associated with the changes in the policy under dispute should be timed with the application of the policy itself because the timing of the initiation of the dispute may be determined by a number of other factors.

The first question raised by this particular timing characterization is how to handle the 68 'no policy change' disputes. These are disputes for which the allegation is not that the respondent implemented a new WTO-inconsistent policy, but that the respondent failed to reform a policy that was no longer consistent with the new obligations taken on by joining the WTO. Our approach is to proceed in two steps. First, we report information from the year prior to the initiation of the WTO dispute on the market access at stake in this particular subsample of the caseload. However, we argue that even these

\footnotetext{
${ }^{11}$ We define unit values as the ratio of the constant dollar value of disputed imports to the volume of disputed imports, with volume data defined in kilograms from UN Comtrade made available via WITS. In order to make this variable meaningful across disputes that have different products, we report these bilateral data relative to the average unit value of imports for the disputed products. As a specific example, let $M_{i j k}\left(V_{i j k}\right)$ be respondent $i$ 's volume (value) of imports of disputed product $k$ from exporting country $j$. We then define the relative unit value between $i$ and $j$ of product $k$ as $p_{i j k} \equiv\left(V_{i j k} / M_{i j k}\right) /\left(\left(\sum_{j} V_{i j k}\right) /\left(\sum_{j} M_{i j k}\right)\right)$. In the analysis below, we use this variable to describe potential differences in the price of respondent imports when exporting country $j$ is the complainant versus when exporting country $j$ is an interested third party or even a non-participant in the formal dispute.

${ }^{12}$ Note that because trade volumes are not always reported in the HS-06 data from UN Comtrade, we are able to calculate unit values for only 84 percent of our sample of disputes alleging newly imposed policies. Logit-based tests suggest that missing volume data may not be randomly distributed across 2-digit HS Chapter, with products from the stone and glassware HS sections, for example, being more likely than others to have missing data on volumes. However, this should not bias our results given that only five of the 308 disputes in our sample involved these products. Similar tests for potential differences of availability of volume data across different respondent (importing) countries reveal no evidence of bias.

${ }^{13}$ The timing distinction matters empirically as in two-thirds of the disputes these two years are not the same; one quarter of the disputes in our sample are filed one to two years after the actual violation has occurred, while other disputes are filed as many as 18 years after the alleged violation.
} 
data elicit less information from which to draw inference. Second, and more importantly, we drop these disputes from the sample in which we examine details of the inter-temporal changes to trade flows associated with the timing of implementation of WTO-inconsistent policies coming under dispute.

Consider next the subsample of WTO disputes triggered by a respondent's change to its policy, and thus for which there is data from both before and after the disputed policy went into effect. Our questions of interest include whether different inter-temporal changes in bilateral trade are associated with different types of policies or participation decisions by countries across disputes. So as to avoid partial year effects, we define variables that compare changes to the import data from the first full year after the policy change went into effect relative to the year prior to the policy change. We construct measures by dispute for changes to the value of imports (in 2005 constant US dollars and in percent changes), the percent change in the volume (quantity) of imports, the percent change in prices (unit values), and the change in the respondent's import market share. Nevertheless, we do provide the additional caveat that bilateral trade data at the product level can be quite volatile when measured at the annual frequency, potentially for reasons that have little or nothing to do with the imposition of any particular policy. While the results that we present below do rely on data defined at the annual frequency, the qualitative pattern of our basic results holds under alternative definitions of the data, such as use of two-year averages.

Finally, the terms-of-trade theory suggests that changes to exporter-received prices may be of central interest when examining the role of trade agreements, and by extension, its dispute settlement procedures. Indeed, large importing countries with market power may utilize trade agreements to neutralize their otherwise unilateral incentives to implement policies that impose externalities on trading partners by lowering the prices that exporters receive for products sold. Our approach is to use the variation across different types of disputes and across different exporting countries to begin to investigate the potential impact of the disputed policies on exporter-received prices. However, it is important to clarify that our measures of exporter-received prices are unit values constructed from importer-reported data. While such data are more reliable than exporter-reported data, they are compiled on a c.i.f. basis and thus include the insurance and freight costs that accrue in getting the product from the exporter to the importer's (respondent's) border. For our analysis below that examines changes to these unit prices over time, our estimates will be unaffected by any across-product differences in levels of these freight and insurance costs, provided any cost differentials do not change substantially during the years around the policy change. ${ }^{14}$

\footnotetext{
${ }^{14}$ It is important to note in our penultimate section that provides a comparison of price levels across exporters of products under dispute that we cannot rule out that differences arise due to c.i.f. differences across export sources.
} 


\subsection{WTO disputes and the levels and scope of imported products}

First consider the trade statistics for the 308 WTO disputes involving import policies that can be mapped to HS-06 products. We identify potential heterogeneity across the broad caseload through examination of three different variables related to the disputed imports: the scope of product coverage, the potential dollar value of impacted trade flows, and the bilateral import market shares.

\section{A significant share of WTO disputes involve small amounts of trade and few products, while a significant share also involve large amounts of trade and many products.}

Figure 2 presents our first important result which is evidence of vast heterogeneity in bilateral imports between the complainant and respondent across disputes. The distributions of both product counts and the value of trade in bilateral disputes are both monotonically decreasing, with extremely long tails (truncated in the Figure). First, 17.2 percent of cases covered only one HS-06 product, and 14.0 percent of cases involved annual bilateral trade in disputed products that covered less than $\$ 1$ million per year. ${ }^{15}$ Such a large number of small stakes disputes is perhaps surprising, given that the minimum private sector legal fees for litigating even a relatively simple dispute through to the basic Panel Report stage are likely to range from $\$ 250,000$ to $\$ 750,000$, depending on the law firm involved. ${ }^{16}$ On the other hand, 19.5

\footnotetext{
${ }^{15}$ There are 17 disputes, or roughly 6 percent of this sample, for which bilateral trade in the disputed product is zero in the year prior to the alleged policy violation under dispute. We are generally able to rule out the potential concern that these are disputes with sizeable imports that are simply being unreported in the data, perhaps due to miscoding of the disputed products. For example, in 8 of these disputes, the data reveal positive respondent imports in the disputed product from some other exporting country. Furthermore, in 7 other disputes we observe positive levels of bilateral trade for the disputed product in the year of the violation (just not the year before), suggesting that the violation is occurring in the same year that the complainant starts exporting to the respondent. Finally, the other disputes also appear related to issues of market entry; e.g., Argentina initiated a dispute attempting to remove policies that would allow it to enter the Indian pharmaceutical market, New Zealand initiated a dispute attempting to remove strict phytosanitary barriers so as to enter the Australian apple market, and the Ukraine initiated a dispute against Moldova's environmental restrictions.

${ }^{16}$ This is based on confidential interviews with a small sample of private sector lawyers based at different law firms with significant experience working on WTO litigation. Each was given the following identical hypothetical scenario, "Suppose your firm were to litigate from inception through the Panel Report (only, no appeal) a relatively straightforward WTO dispute between two transparent and small countries. As a more concrete example, suppose the litigants are two Central American countries and you are hired by the complainant to pursue a formal dispute over the other country's allegedly WTO-inconsistent application of an antidumping duty. Assume furthermore that this particular dispute did not involve supplemental costs such as hiring expert economic witnesses or providing other outside technical expertise. What is your best estimate for what the minimum charge to the client in litigation fees would be for the work?" This is in line with what we note is even the Advisory Centre on WTO Law's estimated charges of $\$ 200,000$ to its Category B members (ACWL, 2007); i.e., the true costs to the Advisory Centre for legal services provided are also subsidized by its endowment (established from high-income country donors) and membership fees.
} 
percent of cases covered more than 50 HS-06 products, and 14.9 percent of the caseload involved annual bilateral trade between the complainant and the respondent in disputed products that was more than $\$ 1$ billion per year.

[Figure 2 here]

Table 2 provides additional detail from both the means and quartiles of the distribution for these variables, as well as the levels of the bilateral (complainant-respondent) import market shares for the disputed products. First, the mean number of products at issue in a WTO dispute is 84.2 HS-06 codes, whereas the median number of products affected in a dispute is only 6.5. Second, the mean value of bilateral (respondent from complainant) imports in the disputed products is $\$ 742.7$ million, whereas the median value is only $\$ 66.1$ million. Third, the mean of the complainant's share of the respondent's import market covering these disputed products was 21.0 percent, whereas the median share is only 11.7 percent.

\section{[Table 2 here]}

Furthermore, at the lower end of the distribution in Table 2, a full 25 percent of disputes challenge policies that affect two or fewer HS-06 products, less than $\$ 5.0$ million in bilateral imports, and where the complainant had less than a 2.5 percent share of the respondent's import market in the disputed products. At the upper end, 25 percent of the cases feature WTO challenges to policies that cover more than 34 HS-06 products per dispute, more than $\$ 472.0$ million in bilateral trade in the disputed products, and in which the complainant had more than a 28.6 percent share of the respondent's import market in the disputed products. The number of HS-06 products and the value of bilateral imports reveal means that are significantly higher than the values at the $75^{\text {th }}$ percentile of the distribution; this indicates that there are a few (outlier) disputes at the upper end of the distribution covering large numbers of products and extremely large values of bilateral trade in the disputed products.

How do we understand the extreme heterogeneity in the scope of product coverage as well as the levels of trade under dispute across the distribution of cases? To begin, it is important to reiterate that research cannot explain the distribution of cases that arise without some consideration of both the WTOinconsistent policies that go unchallenged by dispute settlement and some creative empirical strategy to address potential selection effects. However, we speculate here on potential contributing factors for future 
research. Assume, for example, that governments make their decision to litigate over a particular trading partner's WTO violating policy using some sort of welfare-maximizing, expected cost-benefit calculus. ${ }^{17}$

First, complainant countries may face different costs to litigate otherwise identical cases. For example, introduction of the Advisory Centre on WTO Law (ACWL) in 2001 has established at least a two-tiered cost structure for potential litigants - low-income country users of the ACWL receive highly subsidized legal services to which non-users of the ACWL do not have access. ${ }^{18}$

Second, the government's objective function used to decide whether to challenge any potential WTO violation may be more complex than that implied by this simple one time, social-welfare maximizing cost-benefit framework. Governments may also be motivated by domestic politics and place a higher weight on the benefits arising to particular domestic firms with trade dispute interests relative to its costs (Davis, 2012). Alternatively, even national-welfare maximizing governments may pursue disputes in which the economic costs exceed the industry-level benefits if the expected outcome arising from that dispute has significant positive externalities. For example, potential externalities may include precedent-setting (Pelc, forthcoming), especially if this model is reformulated as a repeated game. ${ }^{19}$

Third, the set of potential violations for countries to choose between when deciding which disputes to initiate may not be unbiased. Maggi and Staiger (2011), for example, provide a theory that motivates selection bias as arising endogenously based on dispute settlement rulings. Furthermore, Bown (2002, 2004a) motivates selection bias as resulting from countries being more likely to violate rules by imposing policies ex ante against trading partners with limited trade retaliation capacity, given that retaliation is the ultimate enforcement remedy in WTO dispute settlement.

\footnotetext{
${ }^{17}$ The level of trade is frequently used as a proxy for the size of the economic profits associated with the trade; i.e., higher economic profits implies more resources that would be available to pay for the litigation costs associated with enforcement. For a greater discussion of these issues in the context of WTO dispute settlement, see Bown (2009, chapter 5).

${ }^{18}$ Between its inception in 2001 and 2011, the ACWL provided the legal services on behalf of either a complainant or respondent in more than 35 WTO disputes, or almost 20 percent of all disputes filed during that period. If the ACWL itself were a WTO member country, it would be the third most frequent litigant during the period trailing only the US and EU and ahead of China. Bown and McCulloch (2010) provide an empirical exploration into a number of different margins along which the introduction of the ACWL into WTO dispute settlement may be affecting the pattern of the subsequent caseload. Busch, Reinhardt, and Shaffer (2009) provide a broader review of the WTO legal capacity concerns of low-income countries.

${ }^{19}$ Alternatively, an interpretation of the simultaneous Boeing-Airbus disputes is that they were part of a prisoner's dilemma-like subsidy-setting game, whereby the US and EU used dispute settlement as an attempt to coordinate (or self-enforce) a reciprocal reduction of subsidies.
} 
Our final thought experiment for this section is to use these market access data to provide a rough estimate of the economic importance of the total trade at stake in these disputed products. For the 308 cases initiated between 1995 and 2011, the aggregate annual value of (pre-dispute) respondent imports in disputed products was $\$ 937.5$ billion, or an average of more than $\$ 55$ billion per year. Put differently, this suggests that, on average, the WTO's dispute settlement system was asked to scrutinize policies that covered trade in products that were roughly 0.5 percent of total world imports in $2011 .^{20}$

\subsection{WTO disputes that challenge newly-imposed policies versus non-reformed policies}

The statistics in Table 2 also allow for examination of potential differences across WTO disputes, depending on whether the complainant's allegation is that the respondent implemented a WTOinconsistent policy or that the respondent did not change a policy that its membership in the WTO requires. We do not have any theoretically-motivated expectations of potential differences that might arise depending on these two types of violations. At this stage, we only reiterate that there are more problems with measuring the market access associated with 'no policy change' types of disputes. ${ }^{21}$

\section{There is little difference in the levels of trade for WTO disputes involving policy changes versus the disputes over the failure to implement policy changes.}

There are two main takeaways from a comparison of the data on WTO disputes involving policy changes versus those that allege failure to change a policy to implement WTO commitments in Table 2 . The first is a simple confirmation of the disparity in the range of market access described earlier - across both

\footnotetext{
${ }^{20}$ This $\$ 937.5$ billion includes bilateral imports between the complainant and respondent in disputes associated with 'partial' policies, and all respondent imports in the disputed products when the dispute is associated with an alleged 'global' policy. For 'policy change' disputes, the pre-dispute year is the year prior to the implementation of the disputed policy. The subsequent back of the envelope calculation is derived by using the WTO's world import figure in 2011 (excluding intra-EU trade) of $\$ 14,485$ billion, which we use our price deflator to convert to $\$ 10,882$ billion (in 2005 dollars); i.e., $\$ 55$ billion is 0.5 percent of total world imports in 2011.

${ }^{21}$ For the "no policy change" category of WTO disputes, we are forced to rely on data from the year prior to the initiation of the WTO dispute, since we have not observed a pre-dispute year in which an arguably WTO-consistent policy had been in effect. In these disputes, the product coverage and the import market share variables may contain some useful information; nevertheless, the data on import values are only likely to reveal a lower bound for the level of the complainant's market access interests. The count of HS-06 products defined in the dispute is likely to be unbiased; however, estimates of even the complainant's share of the respondent's import market are not likely to accurately reflect the relative importance of the complainant to the import market if the respondent's policy (that has never been made WTO consistent) had been imposed on a basis that violates basic MFN treatment.
} 
types of violations, there is vast heterogeneity in the scope of HS-06 products, dollar values of imports, and complainant's share of the respondent's import market of the disputed products.

The second result is that there are no statistically significant difference between the value of trade involving 'policy change' versus 'no policy change' disputes. This evidence is based on the KolmogorovSmirnov (K-S) test that compares the distributions across subsamples of disputes, a non-parametric test that is sensitive to differences in both the location and the shape of the two cumulative distribution functions. K-S tests reveal some evidence that the import market shares of complainants are lower in the 'no policy change' disputes, and that the scope of product coverage is somewhat higher in the 'no policy change' disputes. Nevertheless, we do not stress these differences given the underlying measurement concerns for these market access indicators for the smaller subsample of 'no policy change' disputes.

\subsection{WTO disputes over policy changes and changes to complainant-respondent trade}

Next consider Table 3, which provides summary statistics on the subsample of 240 disputes in which the respondent is alleged to have imposed a newly WTO-inconsistent policy. The lower two-thirds of the table reveals new indicators for the changes in bilateral (complainant-respondent) trade in the disputed products associated with the timing of the imposition of the policy.

[Table 3 here]

The value of bilateral trade in products subject to the WTO dispute tends to fall after imposition of the allegedly WTO-inconsistent policy, with immediate declines on average for both import volumes and prices.

To begin, there is evidence of a basic decline in respondent imports from the complainant in the disputed products associated with the timing of the imposition of an allegedly WTO-inconsistent policy. Once again, these data do not control for a number of other factors that may also influence how trade changes over time. Across disputes, Table 3 reveals that the value of bilateral imports in the disputed products fell by an average of $\$ 56.3$ million, and the average decline in bilateral imports was a 21.5 percent. Furthermore, complainants suffer an average of a 2.2 percentage point reduction in their share of the respondent's import market in the disputed products. Nevertheless, because the standard deviations in the 
data reported in the table remain sizeable, we conclude that there is also substantial heterogeneity across the distribution of disputes. ${ }^{22}$

Table 3 also breaks out the inter-temporal changes in trade values associated with the timing of the allegedly WTO-inconsistent policy to changes in trade volumes and prices of the complainant's exports of the disputed products. Basic economic theory predicts that a respondent's implementation of an import-restricting policy would shift backward the downward-sloping import demand curve. The result of this shift should be a reduction to both the equilibrium level of import volumes (quantities) and prices, ceteris paribus. The results from the first column of Table 3 indicate that these policy changes are associated with reductions, on average, to both trade volumes and exporter-received prices. Nevertheless, we caution against any temptation to compare the size of the average volume reduction to the price reduction in order to draw inference on disputed product elasticities, especially without any comparable information on the patterns for products subject to WTO-inconsistent policies that have gone unchallenged by formal disputes. ${ }^{23}$ Such a comparison is not particularly meaningful in isolation for a number of reasons, including because prices are likely to be 'sticky' in the short run period over which we are measuring changes in exporter-received prices around the imposition of the policy.

As a final thought experiment for this section, consider the cumulative change in market access aggregated over all 240 disputes initiated between 1995 and 2011 that are associated with a newlyimposed and allegedly WTO-inconsistent policy. Such an aggregation reveals that, in total, imports in the disputed products were $\$ 60.4$ billion less in the year after the policy change than they were in the year prior to the policy change that is subjected to the WTO litigation. ${ }^{24}$

\subsection{Dispute characterization, by country income categories}

The second set of columns in Table 3 allows for a comparison based on whether the complainant was a high or low-income economy. This may be a useful comparison given the policy concern that low-income countries may not have sufficient access to dispute settlement to protect their market access interests

\footnotetext{
${ }^{22}$ At the upper end of the distribution, there are also some disputes in which bilateral trade in the disputed products and the complainant's import market share actually increase after imposition of the policy.

${ }^{23}$ Some import demand and foreign export supply elasticity estimates are available in the literature from, for example, Kee, Nicita, and Olarreaga (2008) and Broda, Limão, and Weinstein (2008), respectively.

${ }^{24}$ This value includes the change in bilateral imports in the disputed product between the complainant and respondent in disputes associated with partial policies, and the change in all respondent imports in the disputed products when the dispute is associated with an alleged global policy.
} 
because it is complex and costly. To what extent are low-income complainant disputes different from high-income complainant disputes?

Disputes with high income complainants involve more products and bilateral trade that is larger in value; however, scaled measures indicate similar changes to market access for disputes initiated by low-income complainants.

Table 3 provides evidence from a number of indicators that high-income complainants initiate disputes with more market access at stake, on average, than low-income complainants. In particular, high-income complainants initiate disputes that involve more HS-06 products and larger import values for those products under dispute; the K-S tests indicate statistically significant differences between these two distributions overall. Furthermore, the mean count of HS-06 products is 46.3 for low-income complainants as compared to 73.7 for high-income complainants, and the mean value of bilateral imports in disputed products is $\$ 258.9$ million for low-income complainants, compared to $\$ 1.2$ billion for highincome complainants.

Nevertheless, once we redefine the trade data as shares of the respondent's import market or as differences in percentage terms, there are no statistically significant differences in the distribution of disputes initiated by low-income complainants relative to disputes initiated by high-income complainants. And while the differences between the two categories of complainants are not statistically significant, it is worth noting that low-income complainant disputes, on average, involve larger percent changes to the value of bilateral imports associated with the timing of the policy change (24.7 percent versus 18.5 percent reduction) and reductions in import market share (3.0 versus 1.5 percentage points) than highincome complainant disputes.

The final two columns of Table 3 present information from the means of subsamples of disputes split by whether the respondent was a low- or high-income country. The main statistical differences between the distributions of these two subsamples of disputes are that, not surprisingly, high-income respondent cases on average feature larger market access levels and larger absolute declines in trade values, and percent declines in trade volumes, relative to cases initiated against low-income respondents. On the other hand, WTO challenges to low income respondent policies involve complainants having significantly larger import market shares and losses to those market shares. 
This section explores potential differences in trade flows associated with disputes that allege the respondent has implemented a WTO-inconsistent policy, based on whether the policy was 'global' versus 'partial.' That is, we examine whether there are differences in trade flows depending on how the policy under dispute was applied to non-complainant exporters.

We begin this section by only comparing complainant-respondent to complainant-respondent trade across the two different policy categories. We then turn to a comparison of the complainantrespondent trade to the third country (non-complainant) - respondent trade, both overall and then broken out by the two types of policies under dispute.

\subsection{Comparing complainant-respondent trade in disputes based on global versus partial policies}

Table 4 compares disputes based on the nature of the respondent's alleged policy and whether it was imposed on a global versus partial basis.

[Table 4 here]

There is little statistical difference in the levels of respondent imports from complainants between disputes involving global policies versus disputes involving partial policies.

Specifically, Table 4 provides evidence of substantial dispersion in product scope, trade value coverage, and the complainant's import market share at stake for both global and partial policy disputes. Both types of policies under dispute feature 2 HS-06 codes per dispute at the $25^{\text {th }}$ percentile, roughly 30 HS-06 products at the $75^{\text {th }}$ percentile, and more than 50 HS-06 products at the mean - indicating a few outliers at the high end of the distribution with large numbers of affected product codes. The two types of disputes involve bilateral (respondent from complainant) trade flows of $\$ 4.3$ and $\$ 5.0$ million at the $25^{\text {th }}$ percentile and of $\$ 420.3$ million and $\$ 449.1$ million at the $75^{\text {th }}$ percentile for global and partial policies, respectively. In both subsamples of disputes, the mean values are also higher than values at the $75^{\text {th }}$ percentile, indicating the presence of a few outliers at the high end of the distribution with large trade values at stake. Finally, the complainant's share of the respondent's import market is also similar in global policy versus partial policy disputes. 
Overall, there is no statistically significant difference in the distributions for the variables characterizing the potential scope and levels of market access at stake based on different types of policies. These results from Table 4 are therefore consistent with what we have already observed in Table 2. Without controlling for other factors - such as income levels or product characteristics - there is no evidence that 'global' versus 'partial' policy disputes on their own feature differences in product scope or levels of complainant market access at stake.

However, a number of inter-temporal measures of the complainant's disputed exports to the respondent behave differently depending on whether the policy under dispute is global versus partial.

The lower half of Table 4 reveals some evidence of differences in changes to complainant-respondent trade associated with implementation of the WTO-inconsistent policies under dispute, depending on the nature of the underlying policy being challenged. The first statistically significant differential arises through a comparison of the distributions of the disputes' percent changes in import values associated with the timing of policy imposition. On average, the value of imports falls by 36.4 percent in partial policy disputes, while it increases by 1.2 percent in global policy disputes. Second, the statistical differences across dispute distributions for the percent changes in import volumes are even stronger; on average, the volume of imports in partial policy disputes falls by 42.0 percent, while import volumes in global policy disputes increase by 5.5 percent. Finally, we point out the potential differences in the changes to exporter-received prices across global versus partial policies, even though the K-S test reveals that differences in the two distributions are not statistically significant. Exporter-received prices fall by an average of 3.2 percent in global policy disputes, whereas exporter-received prices actually increase slightly ( 0.9 percent) on average in partial policy disputes.

Figure 3 presents kernel density estimates of the probability density functions of the global and partial policy subsamples for these three variables in which their changes are defined around the year that disputed policy was implemented: i) the percentage change in value of bilateral, disputed product imports, ii) the percent change in its volume, and iii) the percent change in its exporter-received price. ${ }^{25}$ Again, the figure visually confirms the evidence from the K-S test in Table 4 that the differential percent change in

\footnotetext{
${ }^{25}$ Kernel density estimation is essentially a non-parametric method of estimating probability density functions that operates much like a histogram but incorporates a weighting function (known as the kernel) to smooth the density. The densities in Figure 3 employ an Epanechnikov kernel function.
} 
import values and volumes between global and partial policy disputes is not limited to the means but is also present across the full distributions of disputes.

What might explain the patterns behind the differences between the types of policy under dispute? Compare disputes over global policies - e.g., challenges to implementation of a domestic regulation, subsidy, or tax that the respondent equally applies to all foreign export sources of the product under disputes - to disputes over partial policies - e.g., challenges to implementation of a policy such as antidumping that the respondent selectively applies against the complainant and for which other exporters are excluded. Respondent policies that apply to all exporters lead to relatively smaller losses to trade values and volumes and relatively larger potential declines in exporter-received prices than do respondent policies that apply to a selective set of exporters.

One contributing explanation may be that disputes involving antidumping in particular are different, and this is driving the results of the partial policy sample. ${ }^{26}$ The substantial research literature on antidumping reveals that it has a number of peculiar features as an import-restricting policy. For example, in the United States it may be counterproductive for the (complainant) exporter to attempt to retain market share and stabilize the volume of its exports by further lowering its prices in response to the import restriction. Because the size of the antidumping duty is calculated retrospectively, a further reduction of its export price may simply result in the antidumping authority increasing the size of the calculated dumping margin and thus the size of the import duty that it imposes. ${ }^{27}$

On the other hand, it is also important to point out that these particular differences may be spurious and arise due to standard problems of using unit values at the HS-06 level, which can be a relatively noisy measures of prices. For example, the HS-06 level is still relatively aggregated in that it is may be comprised of many underlying varieties of HS-08 or HS-10 varieties with different uses, made of different qualities and by heterogeneous firms with differential markups. As an extreme example to illustrate the point, suppose a respondent's policy targets only the lowest-priced HS-08 variety and completely eliminates all imports of that variety. The result may be that unit values at the HS-06 level increase even though the HS-06 level price increase does not reveal any useful information about the

\footnotetext{
${ }^{26}$ Disputes over antidumping account for 62 percent of our subsample of partial policies, and a large share of these antidumping disputes challenge US-imposed antidumping. While not reported in the table, a comparison between antidumping and other partial policy disputes indicates that antidumping violations are associated with even larger decreases in trade volumes (46.2 percent compared to 34.1 percent on average) and increases in unit prices (1.9 percent increase compared to a 0.9 percent decrease on average), although these differences are not statistically significant.

${ }^{27}$ Blonigen and Haynes $(2002,2010)$, for example, provide a discussion and empirical analysis of US antidumping duties and implications for export prices based on an Canadian steel exports. See also Kelly (2010).
} 
price change happening at the underlying HS-08 level by definition. An open research question is whether there are any greater measurement problems involved in using HS-06 data for partial policy disputes, relative to global policy disputes.

We conclude this section by considering why potential differentials may be useful for empirical research on determinants of WTO dispute settlement activity. Consider, for example, a study like Bown (2005b), that explores the question of which of the exporters hit by previously-imposed antidumping duties will ultimately challenge those duties under formal WTO dispute settlement, or a modified version of Bown (2005a), that would examine the set of all previously-imposed and MFN-conforming global safeguard measures and the question of which of those exporters will challenge those measures. Would any of the measures in Table 4 that indicate evidence of differences between policy types under dispute turn out to be useful in explaining the separate (and arguably more important) selection question? Are these potential determinants of which WTO-inconsistent applications of trade policy, out of the universe of all applied policy actions, within a class of policies actually face a formal dispute?

\subsection{Comparing respondent disputed product imports from complainants versus non-complainants}

Our final exercise involves an expansion of the set of exporters of the disputed product to the respondent's market beyond the complainant. We use the disaggregated HS-06 level trade data to reveal all of the countries that export the disputed product to the respondent market. Given that an increasing body of research examines the role of non-complainant exporters in WTO disputes, we argue that an important starting point involves stepping back and understanding the levels of and changes to the trade in the disputed products that non-complainant exporters may also have at stake under WTO litigation. ${ }^{28}$

Consider Table 5 which breaks out non-complainant exporters into two further categories - those exporters that, in the process of the dispute, formally identify themselves as being an interested third party, versus all other 'non-participant' exporters.

[Table 5 here]

Relative to non-complainants, complainants have larger exports and market share, and on average suffer larger market access reductions according to a number of different measures.

\footnotetext{
${ }^{28}$ Examples of research examining various aspects of non-complainant activity in formal WTO dispute settlement include Bown (2004c, 2005a), Busch and Reinhardt (2006), and Johns and Pelc (2013).
} 
First, we use the data on market access levels in Table 5 to compare complainant exports to the respondent in the disputed products to non-complainant exports to the respondent. The first column reveals that, across the entire sample of disputes, complainant exports are larger (\$741.4 million), on average, than exports from formal third parties (\$463.6 million) and nonparticipants (\$43.4 million). Furthermore, the complainant's share of the respondent's import market in the disputed products is much larger (22.7 percent), on average, than the third party exporters' share (6.2 percent), which itself is larger than the non-participants' share (0.9 percent). We note in both instances that the middle and right-most columns of Table 5 indicate that the ordering of these relationships is present across both the global policy and the partial policy subsamples of disputes.

In the full sample of disputes, complainants also tend to suffer larger changes to market access than non-complainants. On average, complainant bilateral exports in the disputed product fall by $\$ 56.3$ million, compared to an $\$ 8.7$ million increase for non-participants and a $\$ 53.7$ million average increase for third parties. The complainant suffers a 2.2 percentage point reduction in its share of the respondent's disputed product import market, whereas the average third party exporter's market share falls by 0.1 percentage point, and the non-participant increases its market share by 0.1 percentage point. The value of the complainant's bilateral exports in the disputed product falls by 21.5 percent, compared to a 3.5 percent reduction for third parties, and an 11.8 percent average increase for non-participants. The volume of the complainant's bilateral exports in the disputed product falls by 24.1 percent, compared to a 3.2 percent increase for third parties, and an 11.2 percent average increase for non-participants.

\section{Among all exporters of the disputed product to the respondent, in global policy disputes, complainants not only experience the largest negative impacts to their export values, volumes, and market shares, but there is weak evidence that their exporters also suffer the largest average decline in prices.}

Once again, the policies in 'global' types of disputes apply to all of the respondent's trading partners. While we admittedly do not control for other factors likely to affect dispute initiation, it is reassuring from this data that the complainant country - which is revealed through its role as the initiator of the dispute as the exporter able to overcome the collective action problem - is much larger on average and more negatively affected by the policy than the average non-complainant exporter.

On the other hand it is important to clarify that we cannot make the same claim for the 'partial' policy subsample of disputes for at least two reasons. The first is because the implemented policy itself is selective; i.e., the respondent may have endogenously used the fact that the complainant is a large 
exporter of the disputed product in its calculation to impose the policy on that country in the first place. Second, Table 5 does not distinguish between different types of non-complainant exporters and thus does not provide information on which countries the respondent treated like the complainant and which the respondent did not apply the policy.

Next, one interesting and new result from the subsample of disputes over 'global' policies concerns the percent change in export prices. Recall that in global policy disputes the allegedly WTOinconsistent policy has been imposed on a relatively MFN-conforming basis that thereby negatively impacts all foreign sources of the disputed product. On average in this subsample, the complainant's exporters suffer a larger decline in their prices for the disputed product (3.2 percent price decline) relative to third parties and nonparticipants (both experience a 1.9 percent decline). While these differences are not statistically significant, their ranking suggests that within the set of disputes over policies that negatively affect many exporting countries, suffering the largest price decline may contribute to why the complainant country is the one to step forward to initiate and potentially litigate the dispute at the WTO.

The impact on prices for the 'partial' policies under dispute is quite different, though this is also subject to caveats. Complainant export prices to the respondent increase by 0.9 percent on average, whereas third country export prices decline by 5.0 percent. This is consistent with an average outcome whereby third party exporters lower their price alongside the respondent's policy imposition against the complainant, perhaps with the intention of increasing their shares of the respondent's import market. While we do not speculate on explanations behind any such pattern, thereby leaving a formal investigation for future research, we do reiterate that confirmation would also require distinguishing between whether non-complainant exporters were subject to or beneficiaries of the allegedly WTOinconsistent respondent's 'partial' policy.

\section{Complainants typically have lower-priced exports of the disputed products to the respondent than the other categories of exporting countries.}

Our final comparison concerns the relative levels of unit prices for the three different categories of exporting countries to the respondent. Interestingly, Table 5 reveals the complainant as the low-priced supplier to the respondent, on average, relative to the third party exporters as well as the nonparticipant exporters. There is evidence of this in the full sample of disputes - i.e., 1.1 for complainants, relative to 1.5 for third party exporters and 6.1 for non-participants - as well as in both the global policy and partial policy subsamples. While we again do not stress these results given the caveats associated with using HS- 
06 unit values to proxy for exporter-received prices, it is still worth considering the potential implications of the complainant being the low-priced exporter.

First, such an empirical result would be mildly surprising for the sample of 'global' policy disputes for at least one reason. Recall in global policy disputes that the respondent's alleged WTOviolating policy does not single out one exporter but is instead imposed on a relatively MFN-conforming basis that adversely affects all foreign sources of the disputed product similarly. The empirical evidence and intuition drawn from the 'quality ladders' literature (e.g., Schott, 2004; Khandelwal, 2010) suggests that higher prices across exporters within a HS-06 product category may be indicative of varieties that are of higher quality, and produced by firms that can potentially charge higher mark-ups and earn higher profits. However, if there is a significant fixed cost to any particular exporter pursuing a WTO dispute as a complainant, then within the set of all exporters of a disputed product to the respondent, we might expect higher-priced exporters to have the greatest capacity to take the lead in initiating WTO disputes, ceteris paribus. While the approach does not control for other important factors, there is no evidence of this in the data. If anything, the differences between the complainant, third party, and nonparticipant average price levels are larger in global policy disputes than in partial policy disputes.

On the other hand, the result that the complainant has lower average export prices is not unexpected for partial policy disputes, though this is also likely due to policy endogeneity. Again consider WTO challenges to a respondent's policy like antidumping, which makes up a considerable share of the partial policy sample of disputes. In these disputes, the respondent's policy is deliberately applied against exporting countries whose import prices are too 'low.' And while the definition of low is typically made in relation to the exporter's own sales in another market, it is also consistent with prices being low relative to other foreign export sources of those products (such as third parties and non-participants). Finally, for this subsample of 'partial' policy disputes, a further comparison of price changes between complainants and third parties would also need to address whether or not a particular country was excluded from the respondent's policy application.

\section{Conclusion}

This paper establishes a set of basic empirical facts on the product-level trade that is affected by the policies that trigger litigation under the WTO's formal dispute settlement provisions. We construct a new data set that contains a mapping of WTO disputed policies to disaggregated trade data, and we use it to 
characterize the scope, levels, and changes to the trade values, market shares, volumes and prices of products that become subject to litigation.

Our most striking result is the wide variation of levels of affected trade and scope of targeted products across WTO disputes. Nevertheless, we also reveal sensible patterns to the trade data for the policies under dispute. For example, both high- and low-income complainants tend to suffer losses in foreign market access in the products under dispute once the data are scaled as market shares or in percentage terms. We also show the importance of addressing the differences between disputes challenging 'global' versus 'partial' policies, in terms of how the respondent's policy treats noncomplainant trading partners. We find that, relative to partial policy disputes, global policies trigger smaller reductions in import values and volumes, and we even provide some weak evidence of larger reductions in exporter-received prices. Finally, amongst all of the exporting countries affected by global policies, a number of different measures find that the complainant is, on average, much larger and suffers larger average changes to affected trade than the other potential litigants.

Our results contribute to an emerging theoretical literature seeking to model various features of WTO dispute settlement (e.g., Maggi and Staiger 2011, 2013, forthcoming; Staiger and Sykes 2013; Beshkar 2010a,b; and Park 2011). The arrival of additional theory in this is area is especially welcomed, given that a likely contributor to the lack of progress toward a deeper empirical understanding of dispute settlement and its role in trade agreements is because existing research has been only loosely guided by theory. The empirical patterns that emerge from our analysis may be useful in helping to shape theorists' modeling priorities in mutually advantageous ways so that future rigorous empirical work might also be more properly grounded in theory.

A second important goal of this paper has been to present a synthesis of some key facts about market access under WTO dispute settlement. One broad fear is that the failure of the existing literature to provide robust empirical insights about traded products and market access may result in misunderstandings or even mischaracterizations of what WTO dispute settlement is about. A more targeted fear is that the failure of researchers to properly account for potential variation in this critical aspect of the underlying dispute - i.e., the disputed product trade that is adversely affected by the eventual respondent's policy that triggers the dispute - may lead to the standard econometric problem of omitted variable bias. The failure to properly control for the trading interests that countries have in a potential dispute may severely affect the credibility of any empirical results, even if the importance of the trade at stake in the dispute is not the researcher's main question of interest. 


\section{References}

ACWL (2007) "Billing Policy and Time Budget," ACWL/MB/D/2007/7, 19 November, available at http://www.acwl.ch/e/documents/ACWL-MB-D-2007-7.pdf , last accessed July 10, 2014.

Bagwell, Kyle and Robert W. Staiger (2002) The Economics of the World Trading System. Cambridge: MIT Press.

Bagwell, Kyle and Robert W. Staiger (2011) "What Do Trade Negotiators Negotiate About? Empirical Evidence from the World Trade Organization," American Economic Review 101(4): 1238-1273.

Beshkar, Mostafa (2010a) "Trade Skirmishes Safeguards: A Theory of the WTO Dispute Settlement Process," Journal of International Economics 82(1): 35-48.

Beshkar, Mostafa (2010b) "Optimal Remedies in International Trade Agreements," European Economic Review 54(3): 455-466.

Blonigen, Bruce A. and Stephen E. Haynes (2002) "Antidumping Investigations and the Pass Through of Antidumping Duties and Exchange Rates," American Economic Review 92(4): 1044-1061.

Blonigen, Bruce A. and Stephen E. Haynes (2010) "Antidumping Investigations and the Pass Through of Antidumping Duties and Exchange Rates: Reply,” American Economic Review 100(3): 1283-1284.

Bown, Chad P. (2002) “The Economics of Trade Disputes, the GATT's Article XXIII and the WTO's Dispute Settlement Understanding," Economics and Politics 14(3): 283-323.

Bown, Chad P. (2004a) "Trade Disputes and the Implementation of Protection under the GATT: An Empirical Assessment,” Journal of International Economics 62(2): 263-294.

Bown, Chad P. (2004b) "On the Economic Success of GATT/WTO Dispute Settlement," The Review of Economics and Statistics 86(3): 811-823.

Bown, Chad P. (2004c) "Trade Policy under the GATT/WTO: Empirical Evidence of the Equal Treatment Rule," Canadian Journal of Economics 37(3): 678-720.

Bown, Chad P. (2005a) "Participation in WTO Dispute Settlement: Complainants, Interested Parties and Free Riders," World Bank Economic Review 19(2): 287-310.

Bown, Chad P. (2005b) "Trade Remedies and World Trade Organization Dispute Settlement: Why Are So Few Challenged?” Journal of Legal Studies 34(2): 515-555.

Bown, Chad P. (2009) Self-Enforcing Trade: Developing Countries and WTO Dispute Settlement. Washington DC, Brookings Institution Press.

Bown, Chad P. (2013) Temporary Trade Barriers Database. The World Bank, available at http://econ.worldbank.org/ttbd/ , June.

Bown, Chad P. and Meredith A. Crowley (2013) "Self-Enforcing Trade Agreements: Evidence from Time-Varying Trade Policy,” American Economic Review 103(2): 1071-1090. 
Bown, Chad P. and Rachel McCulloch (2010) "Developing Countries, Dispute Settlement, and the Advisory Centre on WTO Law," Journal of International Trade and Economic Development 19(1): 3363.

Broda, Christian, Nuno Limão, and David E. Weinstein (2008) "Optimal Tariffs and Market Power: The Evidence," American Economic Review 98(5): 2032-65.

Busch, Marc L. and Krzysztof J. Pelc. (forthcoming) “Dispute Settlement in the WTO,” In Lisa L. Martin (ed.) Handbook of the Politics of International Trade. Oxford: Oxford University Press.

Busch, Marc L. and Eric Reinhardt (2001) "Bargaining in the Shadow of the Law: Early Settlement in GATT/WTO Disputes,” Fordham International Law Journal 24 (1): 158-172.

Busch, Marc L. and Eric Reinhardt (2002) "Testing International Trade Law: Empirical Studies of GATT/WTO Dispute Settlement," in Daniel M. Kennedy and James D. Southwick (eds.), The Political Economy of International Trade Law: Essays in Honor of Robert Hudec. New York and Cambridge: Cambridge University Press.

Busch, Marc L. and Eric Reinhardt (2003) "Developing Countries and GATT/WTO Dispute Settlement," Journal of World Trade 37(4): 719-735.

Busch, Marc L. and Eric Reinhardt (2006) "Three's a Crowd: Third Parties and WTO Dispute Settlement," World Politics 58 (3): 446-477.

Busch, Marc L., Eric Reinhardt and Gregory Shaffer (2009) "Does Legal Capacity Matter? A Survey of WTO Members," World Trade Review 8(4): 559-577.

Davis, Christina L. (2012) Why Adjudicate? Enforcing Trade Rules in the WTO. Princeton, NJ: Princeton University Press.

Davis, Christina L. and Sarah Blodgett Bermeo (2009) "Who Files? Developing Country Participation in WTO Adjudication," Journal of Politics 71(3): 1033-1049.

Guzman, Andrew T. and Beth A. Simmons (2005). "Power Plays and Capacity Constraints: The Selection of Defendants in WTO Disputes," Journal of Legal Studies 34(2): 557-598.

Horn, Henrik (2006) "National Treatment in the GATT," American Economic Review 96(1): 394-404.

Horn, Henrik and Petros C. Mavroidis (2001) "Economic and Legal Aspects of the Most-Favored-Nation Clause," European Journal of Political Economy 17(2): 233-279.

Horn, Henrik and Petros C. Mavroidis (2008) "WTO Dispute Settlement Data Set 1995-2006," The World Bank. Available at http://go.worldbank.org/X5EZPHXJY0, March.

Horn, Henrik, Petros C. Mavroidis, and Hakan Nordstrom (2005) "Is the Use of the WTO Dispute Settlement System Biased?" in Petros C. Mavroidis and Alan O. Sykes (eds.) The WTO and International Trade Law/Dispute Settlement. Cheltenham, UK: Edward Elgar. 
Johns, Leslie and Krzysztof Pelc (2013) "Who Gets to Be in the Room? Manipulating Participation in WTO Disputes." International Organization, forthcoming.

Kee, Hiau Looi, Alessandro Nicita and Marcelo Olarreaga (2008) "Import Demand Elasticities and Trade Distortions," The Review of Economics and Statistics 90(4): 666-682.

Kelly, Brian (2010) "Antidumping Investigations and the Pass-Through of Antidumping Duties and Exchange Rates: Comment,” American Economic Review 100(3): 1280-1282.

Khandelwal, Amit (2010) “The Long and Short (of) Quality Ladders," Review of Economic Studies 77(4): $1450-1476$.

Ludema, Rodney and Anna Maria Mayda (2013) "Do Terms-of-Trade Effects Matter for Trade Agreements? Theory and Evidence from WTO Countries," Quarterly Journal of Economics 128(4): 1837-1893.

Maggi, Giovanni and Robert W. Staiger (2011) “The Role of Dispute Settlement Procedures in International Trade Agreements," Quarterly Journal of Economics 126(1): 475-515.

Maggi, Giovanni and Robert W. Staiger (2013) “Trade Disputes and Settlement," University of Wisconsin manuscript, November.

Maggi, Giovanni and Robert W. Staiger (forthcoming) "Optimal Design of Trade Agreements in the Presence of Renegotiation,” American Economic Journal: Microeconomics.

Olson, Mancur (1965) The Logic of Collective Action: Public Goods and the Theory of Groups. Cambridge, MA: Harvard University Press.

Park, Jee-Hyeong (2011) "Enforcing International Trade Agreements with Imperfect Private Monitoring," Review of Economic Studies 78(3): 1102-1134.

Pelc, Krzysztof (forthcoming) “The Politics of Precedent in International Law: A Social Network Application," American Political Science Review.

Reynolds, Kara M. (2009) "Why Are So Many WTO Disputes Abandoned?" in James Hartigan (ed.) Trade Disputes and the Dispute Settlement Understanding of the WTO. Bingley, UK: Emerald Group Publishing.

Schott, Peter K. (2004) “Across-product versus Within-product Specialization in International Trade," Quarterly Journal of Economics 119(2): 647-678.

Staiger, Robert W. and Alan O. Sykes (2013) "How Important can the Non-Violation Clause be for the GATT/WTO?” NBER Working Paper No. 19256, July.

Viner, Jacob (1950) The Customs Union Issue. New York: Carnegie Endowment for International Peace. 


\section{Data Appendix}

Trade data: We match each dispute to the six digit Harmonized System (HS-06) codes impacted by the policy under dispute. The dispute settlement database developed by Horn and Mavroidis (2008) includes the HS codes associated with most of the disputes filed prior to 2006. We collect the HS codes associated with later cases from official government documents, including World Trade Organization dispute documents, and domestic reports. In some cases, we translate verbal descriptions of the products in question into HS codes using the appropriate nomenclature. When disputes involve products at a more disaggregate level of trade than the HS-06 level, we report all HS-06 codes within the more aggregate product category. We include product codes associated with any case involving trade in products at the two-digit HS product level or higher levels of aggregation. When necessary, we adjust the HS codes to account for changes in the nomenclature that took place in 1996, 2002, and 2007 using the concordances developed by the United Nations Statistics Division.

We collect import data (both value and where available volume) from UN Comtrade via the World Bank's World Integrated Trade Solutions (WITS) database. Trade values are converted to real imports (2005, constant US dollars) using the IMF's World Import Deflator. ${ }^{29}$

We aggregate the trade data of the countries of the European Union into a single entity; for each dispute the European Union is defined by the countries who were members during the year that the alleged violation occurred, or during the year that the dispute was initiated in those disputes targeting failures to implement Uruguay Round concessions or accession agreements. ${ }^{30}$

Trade Volumes and Unit values: We utilize trade volumes (measured in kilograms) and unit values in our analysis only when we observe volume data for at least 80 percent of the HS-06 codes associated with the dispute. We calculate unit values in the dispute as the volume weighted average of unit values (the observed ratio of the real import value to the volumes reported in the Comtrade database) across HS-06 codes associated with the dispute. Based on these definitions, volume and unit value data are missing for slightly over 17 percent of our sample of 308 disputes.

\footnotetext{
${ }^{29}$ We code all imports classified in the Comtrade dataset as coming from "Asia, not elsewhere specified" as coming from Taiwan.

30 The WITS database is missing trade data for a number of European Union members prior to 1993, thus for the four disputes in which the violation occurred in 1993 the European Union is defined as imports from a seven country subset of members (Germany, Portugal, Greece, Denmark, Ireland, Spain and the Netherlands), while for the single dispute in which the violation took place in 1991, the European Union data includes imports from Germany, Greece and Denmark. We are clearly underestimating the volume and value of trade involved in these disputes.
} 
Policy data: We collect data on whether the dispute is associated with a policy change (and the date of the alleged violation) using WTO dispute settlement documents and other official government documents referring to policy changes, as well as the World Bank's Temporary Trade Barriers Database (Bown, 2013). Disputes that involve regulations that had been implemented prior to 1988 , or were associated with a failure to implement concessions made either during the Uruguay Round Agreement or accession negotiations were classified as involving "no policy change."

Definition of 'global' versus 'partial' policies: Constructed by the authors based on the nature of the allegations involved in the dispute. All disputes that were associated with policy changes that had a differential effect on the respondent's trading partners were classified as a partial policy.

Definition of low-income versus high-income: High-income countries are those the World Bank defined as high-income as of 2012, while low-income countries are all others. 
Table 1. WTO Dispute Characterization, 1995-2011

\begin{tabular}{|c|c|c|}
\hline & $\begin{array}{l}\text { Number } \\
\text { of } \\
\text { disputes }\end{array}$ & $\begin{array}{c}\text { Share } \\
\text { of total } \\
\text { disputes }(\%)\end{array}$ \\
\hline Total WTO disputes (bilateral pair, non-redundant definition) & 427 & 100.0 \\
\hline - Disputes over policies that primarily affect exports & 41 & 9.6 \\
\hline Disputes over policies that primarily affect imports & 386 & 90.4 \\
\hline - Disputes over policies that primarily affect services imports & 11 & $-\quad 2.6$ \\
\hline Disputes over policies that primarily affect goods imports & 375 & 87.8 \\
\hline $\begin{array}{l}\text { - Disputes over policies that affect general imports (no specific } \\
\text { products listed) }\end{array}$ & 67 & $-\quad 15.7$ \\
\hline Disputes over policies that target imported products & 308 & 72.1 \\
\hline $\begin{array}{l}\text { - Disputes over policies in which the allegation is that they were not } \\
\text { reformed (i.e., "no policy change") }\end{array}$ & -68 & $-\quad 15.9$ \\
\hline $\begin{array}{l}\text { Disputes over policies that target imported products in which the } \\
\text { allegation is that newly-imposed policy is WTO-inconsistent }\end{array}$ & 240 & 56.2 \\
\hline $\begin{array}{l}\text { Disputes over such policy changes in which the alleged WTO } \\
\text { violation is due to a 'global' policy, negatively affecting all } \\
\text { exporters }\end{array}$ & -95 & $-\quad 22.2$ \\
\hline $\begin{array}{l}\text { Disputes over such policy changes in which the alleged WTO } \\
\text { violation is due to a 'partial' policy, negatively affecting only } \\
\text { some exporters }\end{array}$ & $-\quad 145$ & $-\quad 34.0$ \\
\hline
\end{tabular}

Notes: see text for definitions. 
Table 2. Bilateral Trade in Products Involved in WTO Disputes over Import Policies, 1995-2011

\begin{tabular}{|c|c|c|c|c|c|c|c|c|c|c|c|c|c|}
\hline & \multicolumn{4}{|c|}{ At means } & \multicolumn{3}{|c|}{$\begin{array}{c}\text { At } 25^{\text {th }} \text { percentile } \\
\text { No }\end{array}$} & \multicolumn{3}{|c|}{ At $50^{\text {th }}$ percentile } & \multicolumn{3}{|c|}{$\begin{array}{c}\text { At }^{75^{\text {th }}} \text { percentile } \\
\text { No }\end{array}$} \\
\hline & $\begin{array}{c}\text { All } \\
\text { disputes }\end{array}$ & $\begin{array}{l}\text { No policy } \\
\text { change }\end{array}$ & $\begin{array}{l}\text { Policy } \\
\text { change }\end{array}$ & $\begin{array}{l}\text { K-S } \\
\text { Test }\end{array}$ & All & $\begin{array}{l}\text { policy } \\
\text { change }\end{array}$ & $\begin{array}{l}\text { Policy } \\
\text { change }\end{array}$ & All & $\begin{array}{l}\text { No policy } \\
\text { change }\end{array}$ & $\begin{array}{l}\text { Policy } \\
\text { change }\end{array}$ & All & $\begin{array}{l}\text { policy } \\
\text { change }\end{array}$ & $\begin{array}{l}\text { Policy } \\
\text { change }\end{array}$ \\
\hline $\begin{array}{l}\text { Number of disputed } \\
\text { HS-06 products }\end{array}$ & $\begin{array}{c}84.2 \\
(243.4)\end{array}$ & $\begin{array}{c}168.6 \\
(415.0)\end{array}$ & $\begin{array}{c}60.2 \\
(158.9)\end{array}$ & $* * *$ & 2.0 & 3.5 & 2.0 & 6.5 & 9.5 & 5.0 & 33.5 & 41.0 & 29.5 \\
\hline $\begin{array}{l}\text { Value of bilateral } \\
\text { imports in disputed } \\
\text { products (millions of } \\
2005 \$ \text { ) }\end{array}$ & $\begin{array}{c}742.7 \\
(2433.6)\end{array}$ & $\begin{array}{c}747.1 \\
(1678.2)\end{array}$ & $\begin{array}{c}741.4 \\
(2611.1)\end{array}$ & & 5.0 & 16.0 & 4.7 & 66.1 & 134.5 & 56.3 & 472.0 & 524.0 & 434.7 \\
\hline $\begin{array}{l}\text { Complainant's share } \\
\text { of respondent's } \\
\text { disputed product } \\
\text { import market }(\%)\end{array}$ & $\begin{array}{c}21.0 \\
(25.4)\end{array}$ & $\begin{array}{c}15.3 \\
(21.1)\end{array}$ & $\begin{array}{c}22.7 \\
(26.3)\end{array}$ & $* *$ & 2.5 & 0.6 & 3.4 & 11.7 & 5.8 & 13.6 & 28.6 & 18.5 & 30.2 \\
\hline $\begin{array}{l}\text { Number of } \\
\text { observations } \\
\text { (disputes) }\end{array}$ & 308 & 68 & 240 & & & & & & & & & & \\
\hline $\begin{array}{l}\text { Notes: variables construc } \\
\text { the WTO request for con } \\
\text { distributions for the 'poli }\end{array}$ & $\begin{array}{l}\text { from } \mathrm{HS} \\
\text { ations for } \\
\text { hange' } \mathrm{v}\end{array}$ & $\begin{array}{l}\text { import da } \\
\text { "no polic } \\
\text { us 'no poli }\end{array}$ & $\begin{array}{l}\text { aken fron } \\
\text { hange' di } \\
\text { change' }\end{array}$ & $\begin{array}{l}\text { ye } \\
\text { es. } \\
\text { ites }\end{array}$ & & signi & at $t$ & $r 10$ & ent leve & $\begin{array}{l}\text { utes a } \\
\text { lmog } \\
\text { specti }\end{array}$ & $\begin{array}{l}\text { ar be } \\
\text { innov }\end{array}$ & $\begin{array}{l}\text { he init } \\
\text { f diffe }\end{array}$ & $\begin{array}{l}\text { ion of } \\
\text { ace in }\end{array}$ \\
\hline
\end{tabular}


Table 3. Bilateral Trade in WTO Disputes over Policy Changes, by Income Level

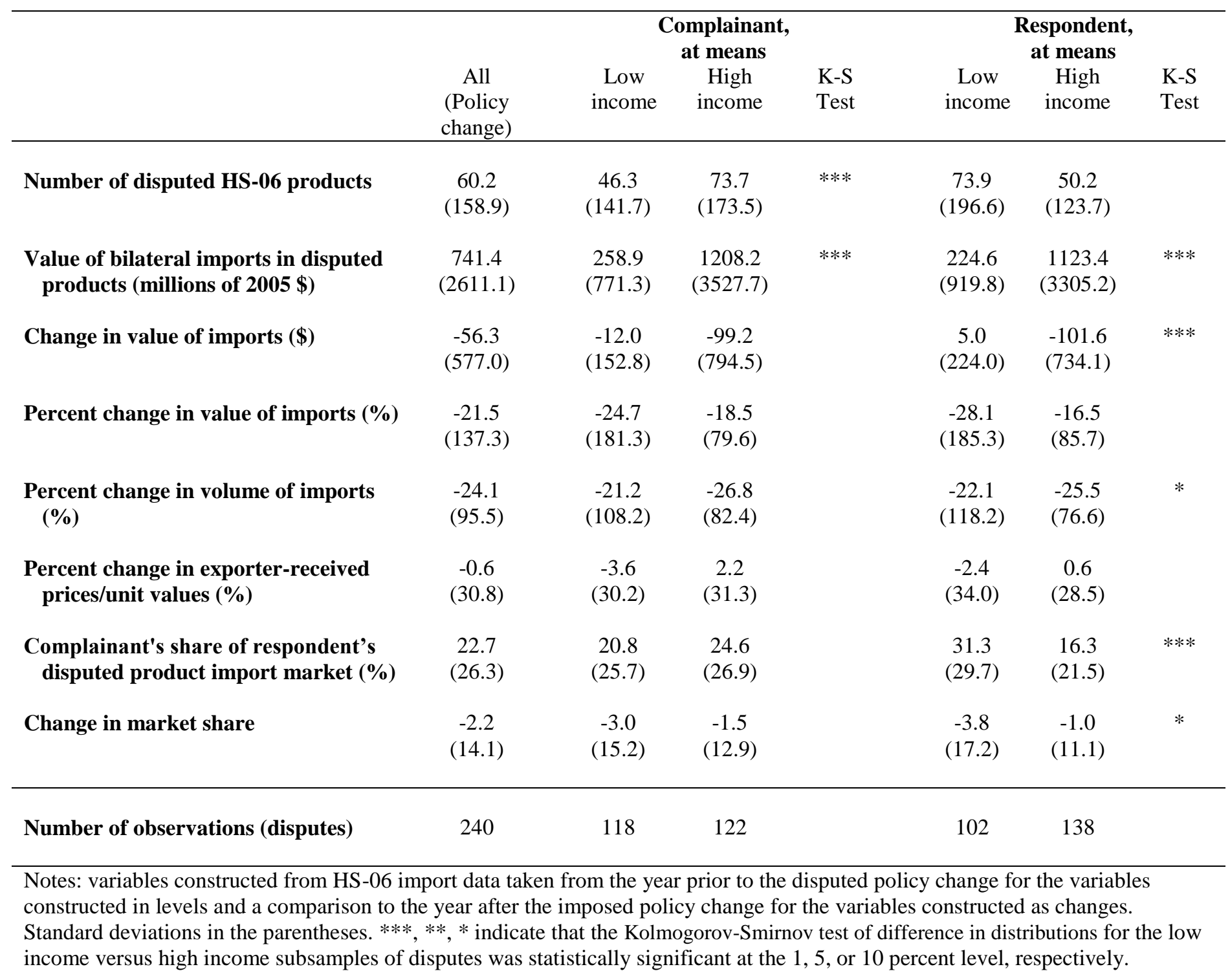


Table 4. Bilateral Trade in WTO Disputes over 'Global' versus 'Partial' Policies

\begin{tabular}{|c|c|c|c|c|c|c|c|c|c|c|c|c|c|}
\hline & \multicolumn{4}{|c|}{ At means } & \multicolumn{3}{|c|}{ At $25^{\text {th }}$ percentile } & \multicolumn{3}{|c|}{ At $50^{\text {th }}$ percentile } & \multicolumn{3}{|c|}{ At $75^{\text {th }}$ percentile } \\
\hline & All & Global & Partial & $\begin{array}{l}\text { K-S } \\
\text { Test } \\
\end{array}$ & All & Global & Partial & All & Global & Partial & All & Global & Partial \\
\hline $\begin{array}{l}\text { Number of disputed HS-06 } \\
\text { products }\end{array}$ & $\begin{array}{c}60.2 \\
(158.9)\end{array}$ & $\begin{array}{c}74.0 \\
(202.2)\end{array}$ & $\begin{array}{c}51.2 \\
(122.6)\end{array}$ & & 2.0 & 2.0 & 2.0 & 5.0 & 7.0 & 5.0 & 29.5 & 32.0 & 26.0 \\
\hline $\begin{array}{l}\text { Value of bilateral imports in } \\
\text { disputed products (millions } \\
\text { of } 2005 \$ \text { ) }\end{array}$ & $\begin{array}{c}741.4 \\
(2611.1)\end{array}$ & $\begin{array}{c}847.2 \\
(2740.0)\end{array}$ & $\begin{array}{c}672.2 \\
(2530.3)\end{array}$ & & 4.7 & 4.3 & 5.0 & 56.3 & 56.8 & 55.9 & 434.7 & 420.3 & 449.1 \\
\hline $\begin{array}{l}\text { Change in value of imports } \\
(\$)\end{array}$ & $\begin{array}{c}-56.3 \\
(577.0)\end{array}$ & $\begin{array}{l}-14.0 \\
(372.0)\end{array}$ & $\begin{array}{l}-84.0 \\
(678.4)\end{array}$ & & -26.2 & -22.0 & -34.4 & -0.6 & 0.0 & -0.8 & 13.3 & 13.6 & 12.0 \\
\hline $\begin{array}{l}\text { Percent change in value of } \\
\text { imports }(\%)\end{array}$ & $\begin{array}{l}-21.5 \\
(137.3)\end{array}$ & $\begin{array}{c}1.2 \\
(143.4)\end{array}$ & $\begin{array}{l}-36.4 \\
(131.6)\end{array}$ & $* *$ & -55.7 & -29.6 & -78.1 & -7.9 & -0.8 & -18.0 & 30.3 & 35.1 & 26.5 \\
\hline $\begin{array}{l}\text { Percent change in volume of } \\
\text { imports }(\%)\end{array}$ & $\begin{array}{l}-24.1 \\
(95.5)\end{array}$ & $\begin{array}{c}5.5 \\
(69.4)\end{array}$ & $\begin{array}{l}-42.0 \\
(104.6)\end{array}$ & $* * *$ & -53.2 & -30.0 & -80.0 & -7.3 & 1.5 & -14.9 & 22.2 & 36.6 & 21.9 \\
\hline $\begin{array}{l}\text { Percent change in exporter- } \\
\text { received prices/unit values } \\
(\%)\end{array}$ & $\begin{array}{c}-0.6 \\
(30.8)\end{array}$ & $\begin{array}{l}-3.2 \\
(34.1)\end{array}$ & $\begin{array}{c}0.9 \\
(28.8)\end{array}$ & & -16.9 & -22.1 & -16.3 & 2.3 & 1.4 & 3.6 & 18.5 & 15.9 & 20.0 \\
\hline $\begin{array}{l}\text { Complainant's share of } \\
\text { respondent's disputed } \\
\text { product import market }(\%)\end{array}$ & $\begin{array}{l}22.7 \\
(26.3)\end{array}$ & $\begin{array}{c}20.4 \\
(23.5)\end{array}$ & $\begin{array}{l}24.2 \\
(27.9)\end{array}$ & & 3.4 & 2.6 & 4.1 & 13.6 & 11.8 & 14.4 & 30.2 & 29.4 & 33.6 \\
\hline Change in market share & $\begin{array}{l}-2.2 \\
(14.1)\end{array}$ & $\begin{array}{c}0.3 \\
(11.0)\end{array}$ & $\begin{array}{l}-3.8 \\
(15.5)\end{array}$ & & -3.9 & -2.4 & -5.0 & -0.5 & -0.3 & -0.7 & 0.9 & 1.1 & 0.7 \\
\hline $\begin{array}{l}\text { Number of observations } \\
\text { (disputes) }\end{array}$ & 240 & 95 & 145 & & & & & & & & & & \\
\hline
\end{tabular}

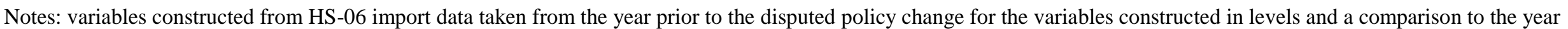

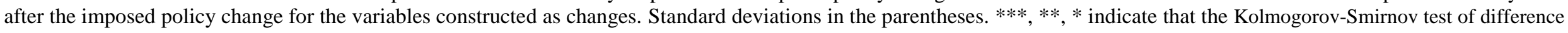
in distributions for the global policy versus partial policy disputes was statistically significant at the 1,5 , or 10 percent level, respectively. 
Table 5. Respondent Imports of Disputed Products from Complainants, Interested Third Parties, and Nonparticipants

\begin{tabular}{|c|c|c|c|c|c|c|c|c|c|}
\hline & \multicolumn{3}{|c|}{$\begin{array}{l}\text { All policy change disputes, } \\
\text { at means }\end{array}$} & \multicolumn{3}{|c|}{$\begin{array}{c}\text { Global policy disputes only, } \\
\text { at means }\end{array}$} & \multicolumn{3}{|c|}{$\begin{array}{c}\text { Partial policy disputes only, } \\
\text { at means }\end{array}$} \\
\hline & $\begin{array}{l}\text { Complain- } \\
\text { ants }\end{array}$ & $\begin{array}{c}\text { Third } \\
\text { parties }\end{array}$ & $\begin{array}{c}\text { Non- } \\
\text { participants }\end{array}$ & $\begin{array}{l}\text { Complain- } \\
\text { ants }\end{array}$ & $\begin{array}{c}\text { Third } \\
\text { parties }\end{array}$ & $\begin{array}{l}\text { Non- } \\
\text { participants }\end{array}$ & $\begin{array}{l}\text { Complain- } \\
\text { ants }\end{array}$ & $\begin{array}{c}\text { Third } \\
\text { parties }\end{array}$ & $\begin{array}{l}\text { Non- } \\
\text { participants }\end{array}$ \\
\hline \multirow{2}{*}{$\begin{array}{l}\text { Value of bilateral imports in } \\
\text { disputed products (millions } \\
\text { of } 2005 \$ \text { ) }\end{array}$} & 741.4 & 463.6 & 43.4 & 847.2 & 429.3 & 46.2 & 672.2 & 489.9 & 41.7 \\
\hline & $(2611.1)$ & $(1391.2)$ & $(411.7)$ & $(2740.0)$ & $(1500.1)$ & $(352.6)$ & $(2530.3)$ & $(1303.4)$ & (442.9) \\
\hline \multirow[t]{2}{*}{ Change in value of imports (\$) } & -56.3 & 53.7 & 8.7 & -14.0 & 95.8 & 9.5 & -84.0 & 21.4 & 8.2 \\
\hline & $(577.0)$ & $(489.1)$ & $(161.2)$ & $(372.0)$ & $(485.4)$ & $(163.8)$ & $(678.4)$ & (490.4) & (159.7) \\
\hline \multirow{2}{*}{$\begin{array}{l}\text { Percent change in value of } \\
\text { imports }(\%)\end{array}$} & -21.5 & -3.5 & 11.8 & 1.2 & 2.9 & 8.4 & -36.4 & -8.3 & 14.0 \\
\hline & $(137.3)$ & $(129.1)$ & $(177.9)$ & $(143.4)$ & $(108.2)$ & $(188.3)$ & $(131.6)$ & $(142.7)$ & $(171.1)$ \\
\hline \multirow{2}{*}{$\begin{array}{l}\text { Percent change in volume of } \\
\text { imports }(\%)\end{array}$} & -24.1 & 3.2 & 11.2 & 5.5 & 4.4 & 10.0 & -42.0 & 2.4 & 11.8 \\
\hline & $(95.5)$ & $(95.9)$ & $(111.0)$ & $(69.4)$ & $(109.5)$ & $(123.4)$ & $(104.6)$ & $(86.2)$ & $(104.5)$ \\
\hline \multirow{2}{*}{$\begin{array}{l}\text { Percent change in exporter- } \\
\text { received prices/unit values } \\
(\%)\end{array}$} & -0.6 & -3.8 & 0.1 & -3.2 & -1.9 & -1.9 & 0.9 & -5.0 & 1.0 \\
\hline & $(30.8)$ & $(39.6)$ & $(56.2)$ & $(34.1)$ & $(48.6)$ & $(73.6)$ & $(28.8)$ & $(32.6)$ & $(45.4)$ \\
\hline \multirow{2}{*}{$\begin{array}{l}\text { Unit value relative to mean } \\
\text { unit value }\end{array}$} & 1.1 & 1.5 & 6.1 & 1.1 & 1.6 & 13.6 & 1.1 & 1.4 & 2.2 \\
\hline & $(0.6)$ & $(1.3)$ & $(176.0)$ & $(0.6)$ & $(1.5)$ & $(298.9)$ & $(0.6)$ & $(1.2)$ & $(10.1)$ \\
\hline \multirow{2}{*}{$\begin{array}{l}\text { Exporter's share of } \\
\text { respondent's disputed } \\
\text { product import market }(\%)\end{array}$} & 22.7 & 6.2 & 0.9 & 20.4 & 5.8 & 1.0 & 24.2 & 6.4 & 0.9 \\
\hline & $(26.3)$ & $(11.4)$ & $(4.4)$ & $(23.5)$ & $(12.5)$ & $(4.9)$ & $(27.9)$ & $(10.4)$ & $(4.2)$ \\
\hline \multirow[t]{2}{*}{ Change in market share } & -2.2 & -0.1 & 0.1 & 0.3 & -0.3 & 0.0 & -3.8 & 0.0 & 0.1 \\
\hline & $(14.1)$ & $(6.1)$ & $(3.5)$ & $(11.0)$ & $(5.5)$ & $(3.7)$ & $(15.5)$ & $(6.5)$ & $(3.4)$ \\
\hline Number of observations & 240 & 539 & 9420 & 95 & 232 & 3491 & 145 & 307 & 5929 \\
\hline $\begin{array}{l}\text { Number of exporting } \\
\text { countries per dispute }\end{array}$ & 1.6 & 3.3 & 48.3 & 1.6 & 4.3 & 51.1 & 1.6 & 2.6 & 46.4 \\
\hline
\end{tabular}

Notes: See Table 4. Means are reported in the table with standard deviations in parentheses. 
Figure 1. WTO Disputes, 1995-2011

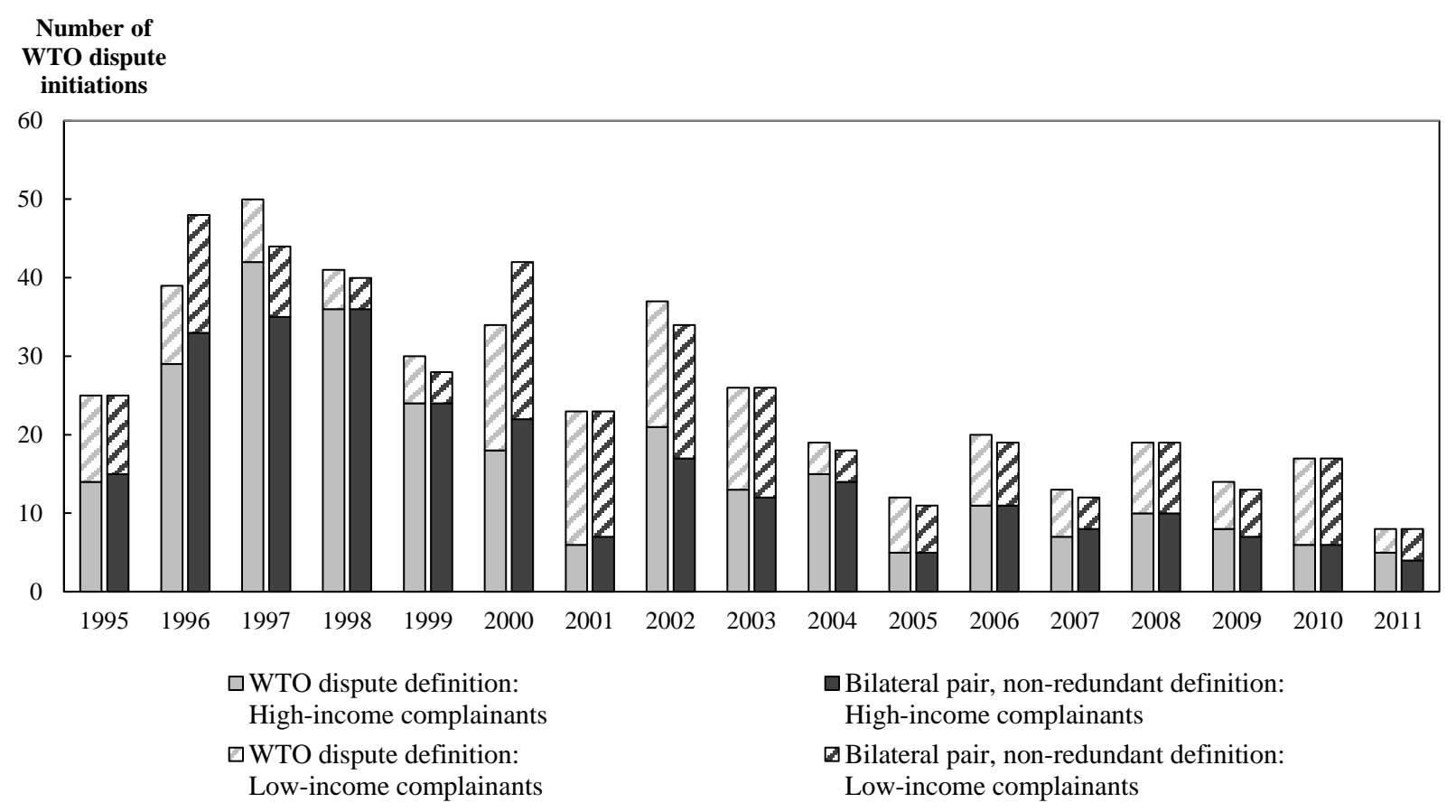

Note: constructed by the authors. 
Figure 2. Levels of Bilateral Trade and Scope of Products Subject to WTO Dispute, 1995-2011

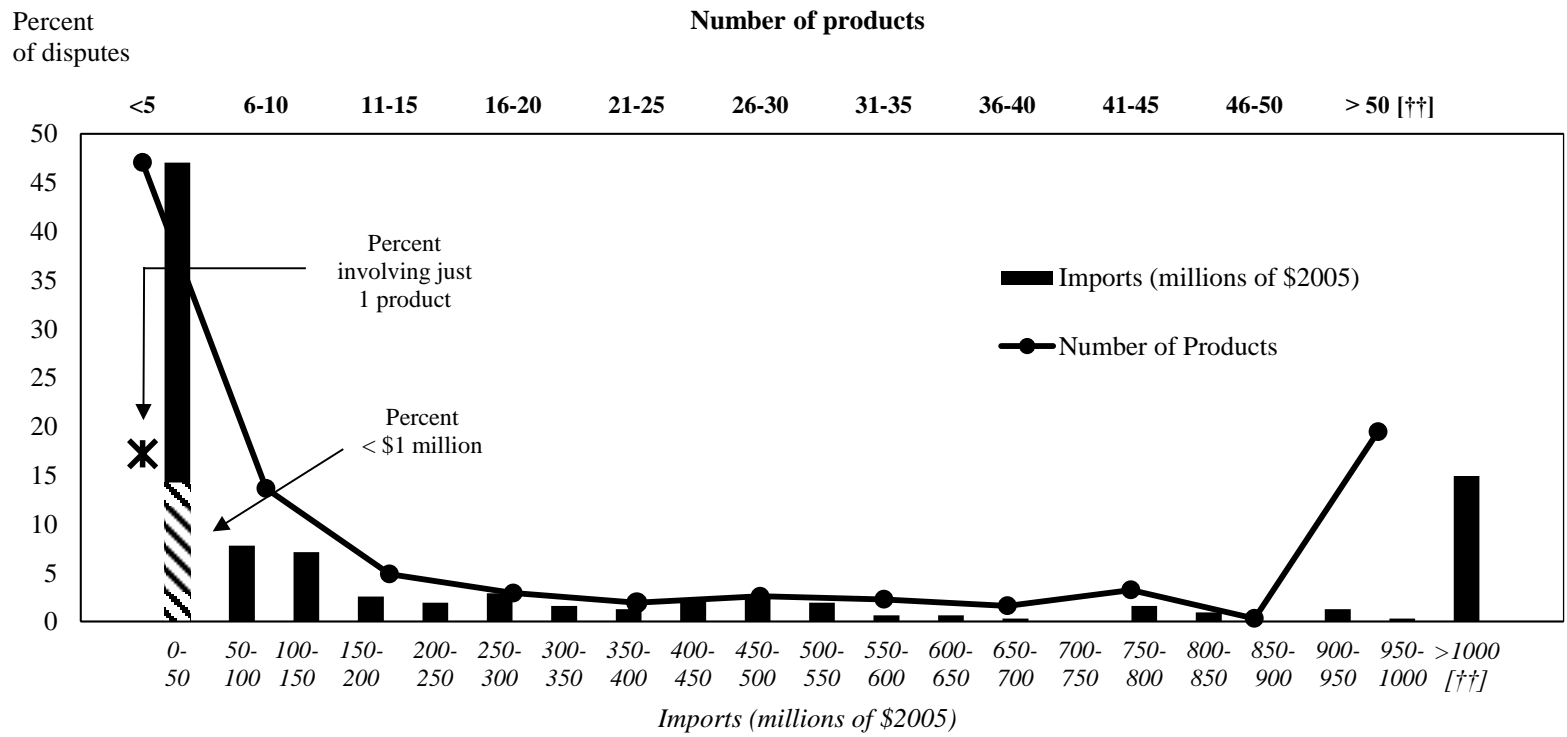

Source: constructed by the authors. [††] indicates that, for ease of exposition and due to the long right tails, we have truncated the right tail at $\$ 1$ billion (for the value of trade) and at 50 products (for the count of HS-06 codes). 
Figure 3. Percent Changes in Trade in Products Subject to WTO Dispute, By Type of Policy

\section{a. Values}

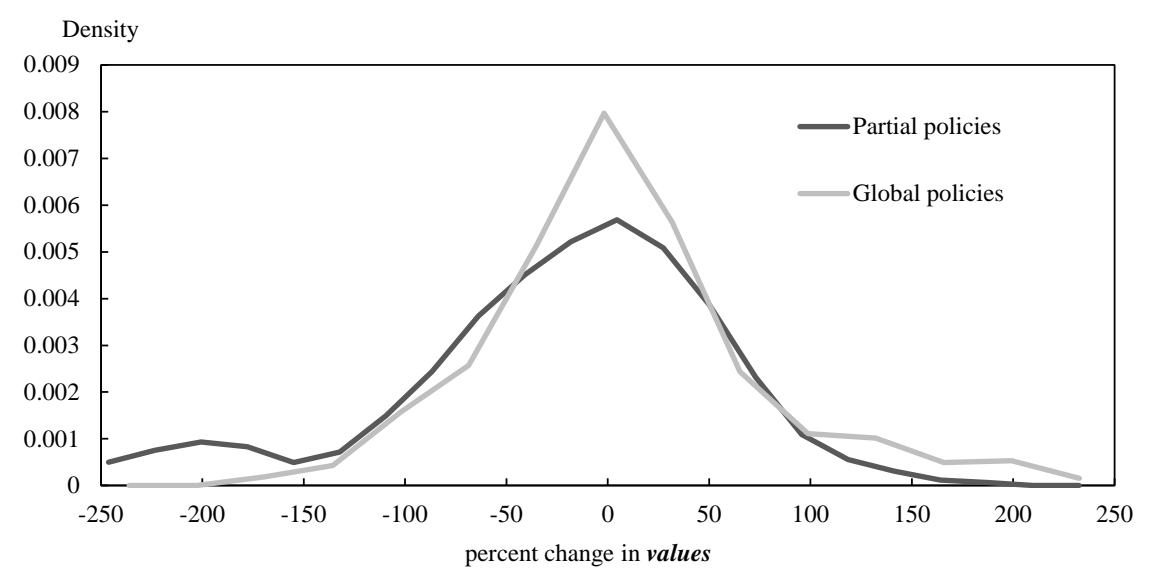

b. Volumes

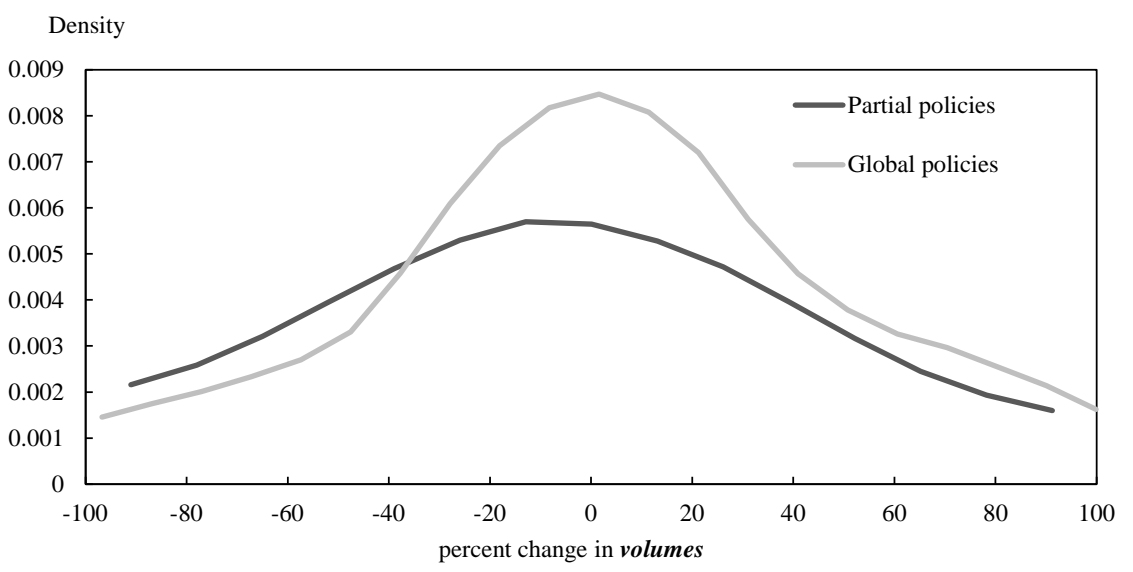

c. Prices/unit values

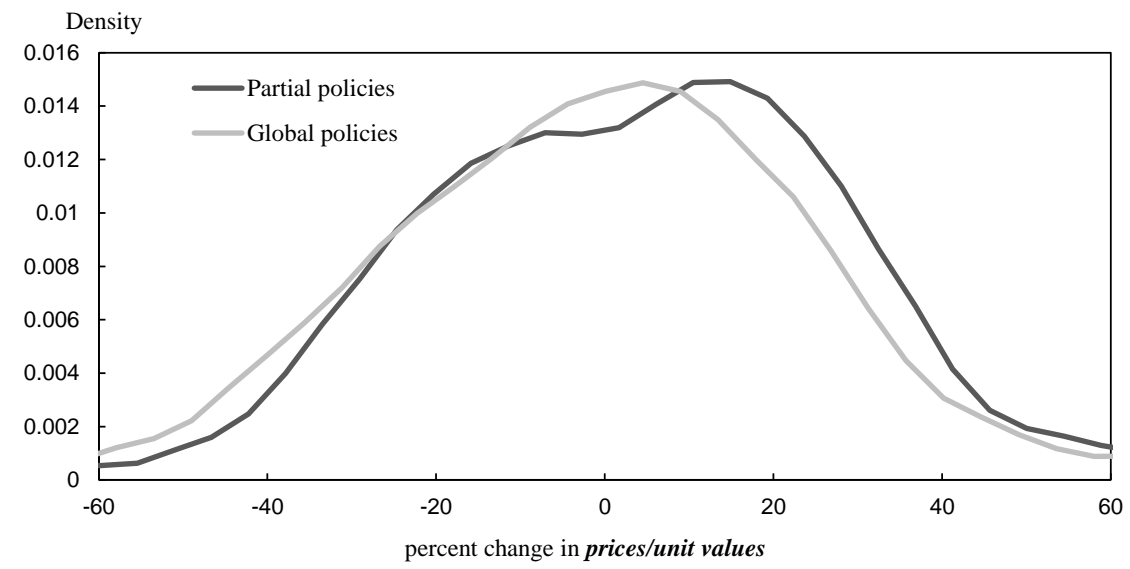

Source: constructed by the authors. Percent change in variable (value, volume, price) of the respondent's bilateral imports of the disputed product from the complainant in the year after the imposition of the alleged WTO violating policy in comparison to the year before the imposition of the policy. Kernel density estimates with tails trimmed. 